\title{
Grassroots of Recordkeeping - An investigation into archival practices within rugby clubs in New Zealand
}

\author{
by
}

\section{Christine Marie Edney}

Submitted to the School of Information Management,

Victoria University of Wellington

in partial fulfilment of the requirements for the degree of

Master of Library and Information Studies 


\section{Acknowledgements}

I would like to acknowledge and thank those who have given me advice, assistance and support through the journey of preparing and writing up this research project.

Firstly I would like to thank my place of employment for the financial support they have given and my work colleagues for their support when the pressure has been on.

I would like to thank Lynley Stone of Victoria University who gave great assistance in the preparation of the last assignment of INFO528. To Gillian Oliver also of Victoria University my grateful thanks for your support and assistance in putting this project together. Your guidance in which way to go has helped develop a small idea into a research project with potential to go further.

To my family thank you for your support and to Lindsay grateful thanks for giving me the support and assistance from a distance. 


\section{Abstract}

The sport of rugby has been officially played in New Zealand since as early as 1870 . In the early years of rugby, the rugby club was one place where the community gathered to participate and communicate. It was a hub of the local community and a place which revealed some of the social history of that community. It is where some memories of the community could be captured and this history now needs to be maintained.

The purpose of this research is to establish what rugby clubs have done to preserve the archives of the club for the future. It is to investigate if these clubs are even aware of what archives they have and what practices they are carrying out to preserve them.

It is these records which contain some of the history of the community and they need to be preserved for future generations so that they can get an insight into the past.

The research has been carried out with the participation of seven rugby clubs in the Wellington region with a visit to each club. A club official was interviewed and at the same time there was an opportunity to view the club premises.

This research established that from those clubs only one had a good understanding of its holdings and had put an archiving plan into action. Another is about to get the assistance of an archivist.

The findings of this research have highlighted the need for education and guidance in the correct archival practices to be carried out. All clubs taking part thought the idea of a manual or guidelines would be of great assistance. If this idea is to be carried through it should be led and encouraged by the clubs' main association, the New Zealand Rugby Union [NZRU]. The idea will need to be promoted to the NZRU to get assistance with development and funding. 
Abstract 1

Contents 2

Chapter one: Background to the research

1 Introduction 5

$\begin{array}{lll}1.1 & \text { Problem statement } & 6\end{array}$

1.2 Need for the study 8

$\begin{array}{lll}1.3 & \text { Research question } & 9\end{array}$

1.4 Definition of key terms 9

$\begin{array}{ll}1.5 & \text { Theoretical framework } \\ 1.6 & \text { Research }\end{array}$

$\begin{array}{lll}1.6 & \text { Research objectives } & 11\end{array}$

$\begin{array}{lll}1.7 & \text { Limitations and Delimitations } & 12\end{array}$

$\begin{array}{lll}1.8 & \text { Human Ethics } & 12\end{array}$

1.9 Conclusion 12

Chapter two: Review of the literature

2 Introduction $\quad 14$

2.1.1 Archives 14

$\begin{array}{ll}2.1 .2 \text { Recordkeeping practices } & 16\end{array}$

$\begin{array}{ll}2.1 .3 \text { Preservation } & 18\end{array}$

$\begin{array}{lll}2.2 \text { Conclusion } & 22\end{array}$

\section{Chapter three: Research design}

3 Introduction 23

$\begin{array}{lll}3.1 & \text { Methodology } & 23\end{array}$

$\begin{array}{ll}3.2 & \text { Procedures } \\ & 3.24\end{array}$

$\begin{array}{lll}3.2 .1 & \text { Pilot interview } & 24\end{array}$

$\begin{array}{ll}3.2 .2 & \text { Collecting data } \\ 3.2 .3 & 25\end{array}$

$\begin{array}{ll}3.2 .3 & \text { Population and sample } \\ 3.2 .4 & 26\end{array}$

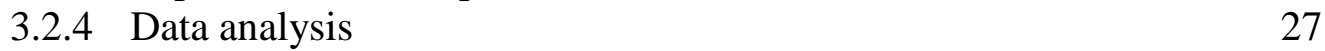

$\begin{array}{lll}3.3 & \text { Conclusion } & 28\end{array}$

Chapter four: Interview Results

$4 \quad$ Introduction $\quad 29$

4.1 Result 29

4.1.1 Role in the club 29

4.1.2 Create records $4.1 .2 .1 \quad$ Minutes 30

4.1.2.2 Correspondence 33

4.1.2.3 Financial 35

4.2.3 Preservation practices 36 
$\begin{array}{lll}\text { 4.2.3.1 Photographs } & 37\end{array}$

4.2.3.2 Trophies 44

4.2.3.3 Club playing jerseys 46

4.2.3.4 Memorabilia/Ephemera 48

4.2.4 Amalgamation $\quad 50$

4.2.5 Histories $\quad 51$

4.2.6 Newsletters $\quad 52$

4.2.7 Computer usage $\quad 53$

4.2.8 Certificate of incorporation, rules $\quad 54$

4.2.9 Information on players $\quad 55$

4.2.10 Annual reports $\quad 57$

$\begin{array}{lll}\text { 4.2.11 Storage standard } & 58\end{array}$

$\begin{array}{ll}\text { 4.2.12 Approved repositories } & 61\end{array}$

4.2.13 Producing guidelines $\quad 62$

$\begin{array}{lll}4.3 & \text { Conclusion } & 63\end{array}$

\section{Chapter five: Conclusions and recommendations}

$5 \quad$ Introduction $\quad 64$

5.1.1 Aware of archives best practice $\quad 64$

$\begin{array}{ll}\text { 5.1.2 Guidelines being practices } & 64\end{array}$

5.1.3 Implications of not following best practice guidelines 65

$\begin{array}{lll}5.2 & \text { Recordkeeping continuum aspect } & 65\end{array}$

$\begin{array}{lll}5.3 & \text { Recommendations } & 67\end{array}$

$\begin{array}{lll}5.4 \text { Conclusion } & 69\end{array}$

$\begin{array}{ll}\text { Reference List } & 71\end{array}$

$\begin{array}{ll}\text { Bibliography } & 73\end{array}$

Appendix

Appendix 1: List of Wellington Rugby Clubs $\quad 74$

$\begin{array}{ll}\text { Appendix 2: Letter to institution } & 75\end{array}$

Appendix 3: Reply from institution $\quad 76$

Appendix 4: Sample letter to participant $\quad 77$

$\begin{array}{ll}\text { Appendix 5: Sample consent form to participant } & 79\end{array}$

Appendix 6: Participant information sheet $\quad 80$

$\begin{array}{ll}\text { Appendix 7: Interview guideline sheet } & 81\end{array}$

\section{List of Tables}

Table 1: Role in the club 30

Table 2: Minutes 33

Table 3: Correspondence $\quad 34$

Table 4: Financial records and legislation 35

Table 5: Preservation awareness $\quad 37$

Table 6: Team photographs 39

Table 7: Trophies $\quad 45$

Table 8: Club jersey, playing strips $\quad 47$ 
Table 9: Memorabilia accounted for 48

Table 10: Newsletter $\quad 52$

Table 11: Computer usage by members 53

Table 12: Rules and certificate of incorporation $\quad 54$

Table 13: Information on members $\quad 55$

Table 14: Annual reports $\quad 57$

Table 15: Storage standard 59

Table 16: Archival institutions $\quad 62$

Table 17: Guidelines for archival practices 63

\section{List of Illustrations}

Figure 1: Minute books 31

Figure 2: Team photographs on club room walls 38

Figure 3: Damage of sun on team photographs $\quad 40$

Figure 4: Flip flop chart used for photograph display 41

Figure 5: Comparison of original photograph to flip flop chart 42

Figure 6: All Black acknowledgement photographs 43

Figure 7: Poor storage causing damage to photographs 44

Figure 8: Trophies in display cabinet $\quad 45$

Figure 9: Club jerseys over the years 46

Figure 10: Display cabinet of memorabilia $\quad 49$

Figure 11: Display cabinet with founder's banner $\quad 50$

Figure 12: Certificate of incorporation $\quad 55$

Figure 13: Storage cupboard $\quad 59$

Figure 14: Minute books in cupboard $\quad 60$

Figure 15: Records stored loose in shelving $\quad 60$

Figure 16: Records stored loose in cupboard $\quad 61$

$\begin{array}{ll}\text { Figure 17: The future of Wellington rugby } & 70\end{array}$ 


\section{Chapter One: Background to the research}

\section{Introduction}

Grassroots rugby is the day-to-day basic level of rugby played in New Zealand. It is where participants starting at age 5 are taught how to play the game, learn the rules, are coached and develop into mature players. The elite few mature players can reach the pinnacle of the game and represent their country as an All Black.

To participate in the sport of rugby players must firstly belong to a club. Many clubs are now well over 100 years old and they hold much social and community history in their records. Researchers, historians and genealogists are looking to these clubs to give them the memories that are required to write up histories and show social development over time. This will not be possible if clubs have not created and correctly maintained their records to provide the evidence of these memories.

Clubs rely on volunteers to run their committee, to look after the records and to put preservation practices into place, but do these volunteers know what is required of them? Do they know where to go to find out what the best archive practices are? The importance of the memory and evidence of the past has only become apparent when the community has gone back to find something that should have been there but has been lost. Minute books, annual reports, financial reports and correspondence all contain information about the development of a community's social history.

One memory of increasing social significance is the involvement of New Zealanders in wars, in particular the First and Second World Wars. Some clubs are now trying to establish a roll of honour of their members who were part of those and other conflicts. 
This research has been undertaken to discover what practices are being carried out amongst a sample selection of rugby clubs in the Wellington region.

The research questions addressed the areas of:

- Creation and maintenance of records

- Knowledge of preservation

- Preservation practices

- Education for volunteers

The findings of this research indicate that because of lack of knowledge archive preservation has not been a priority. With time and some strong guidelines past mistakes can be rectified and records that could be lost can be restored and preserved so that future generations can see back into the past.

\subsection{Problem Statement}

This project sets out to explore what archival practices rugby clubs within New Zealand are implementing for their archival holdings including minute books, correspondence, financial records and photographs. It investigates whether volunteers within the rugby clubs know about archival best practices and whether they understand why they need to follow these practices.

Rugby clubs in New Zealand have been in existence for a long time and form part of the social aspect and history of a local community. The archives which are held by rugby clubs highlight how a community has developed and grown. These archives reveal to what extent the rugby club has influenced social behaviour within the community. They show how the club recordkeeping has changed as technology has changed over the years. Handwritten minute books are now replaced by minutes produced on a computer. The archives of the clubs show which members of that community have achieved greatness and for example have 
represented New Zealand at Olympic and Commonwealth Games, or have become an All Black. Many rugby players have received awards in the Queen's Birthday Honours. One rugby player, William Hardham, who represented the Wellington Rugby Football Union [WRFU] from 1887 to 1899, and in 1908 and 1910, was decorated with the Victoria Cross (the only New Zealander so honoured in the South African War) (Wellington Rugby Football Union, 2008, Hardham Cup). These archives need to be preserved so that the rugby clubs can write their history accurately, honestly and be able to provide the club and its players with stories of earlier achievements.

Rugby clubs are run by volunteers giving their time freely. These volunteers are doing jobs within the club for which they may have no professional training or awareness of what practices they should be carrying out and may not know what is required to preserve the archival holdings. Valuable documentation could be thrown away or left exposed to environmental risk factors such as light, sun, pests and so on. This applies to minute books, annual reports, playing jerseys as well as items in the financial, secretarial, photographic and memorabilia sections of the club. There is a publication Managing and Preserving Community Archives (2005) available from the National Preservation Office, Wellington which provides guidelines on archival practices. Education in recordkeeping, archival practices and guidelines, and preservation of the club's records, especially those of potential historical value, should be encouraged.

This project explores how volunteer-run rugby clubs in New Zealand manage their recordkeeping. The results of this project identify the extent of knowledge and existing practices being carried out by the rugby clubs and make recommendations for further actions. 


\subsection{Need for the study}

There have been many comments and assumptions made about the state of club archives and there tends to be a general consensus that clubs are not good record keepers. The following is a collection take from newspaper articles.

- "A box of minute books and records from two centuries ago has been found stashed at the back of the school's stage"

- "Minute books from before 1922 are understood to have been destroyed in a fire",

- "There was a lost history as there seemed to be pictures with no story on the club walls"3

- “The names of winners of many awards were lost in a club member's computer crash" $^{4}$

- "The club is also interested in hearing from anyone who may be able to shed some light on the whereabouts of the club's first minute book"

- "None of the Marlborough Cricket Association minute books prior to 1938 was available, they had simply disappeared"6

These extracts are from written articles.

- “A lot of material sits in members' cupboards or just stashed away" Smith (1998)

- 'I turned up at the clubhouse to find that the club's records had been taken out of the small storeroom in which they had languished, forgotten and uncared for. The records had been taken out because the storeroom was needed for other purposes" Munro (2000)

\footnotetext{
${ }^{1}$ The Timaru Herald, 4 Sept 2002

${ }^{2}$ The Timaru Herald, 1 Jul 1996

${ }^{3}$ The Southland Times, 1 May 2006

${ }^{4}$ The Southland Times, 1 May 2006

${ }^{5}$ The Timaru Herald, 13 Dec 2002

${ }^{6}$ The Marlborough Express, 24 Jan 2003
} 
What is required is to establish if these comments and statements are correct.

There is a need to establish what archives preservation practices are in place and if there appear to be no practices being carried out are the clubs' administrations aware of what should be done. The best way to do this was to visit a sample of clubs speaking to senior committee members and observing the club room surroundings. At the same time recording what was said would help with analysing and writing a report on the situation at each club.

With the increasing number of clubs writing up their histories there is a need to ensure that the club's growth, development and community involvement is being preserved to make this task easier. By talking to club members they will become more aware of how to go about this.

\subsection{Research questions}

1. To what extent are volunteers in clubs aware of archives best practice?

2. To what extent are these guidelines being practiced?

3. What are the implications of not following the best practice guidelines?

\subsection{Definition of Key Terms}

The following are the key concepts underpinning this research project:

Archive: An archive can be a document, photograph or an item which records an activity which has taken place. "Those records that are appraised as having continuing value" (Kennedy \& Schauder, 1998, p.289). For legal, historical and evidential value records need to be preserved for future reference.

Archival holdings: "The whole of the records and archival materials in the custody of an [institutional or organisational] archive" (Archives New Zealand, 2006). 
Archival practice: What is being done to preserve the archives of the club to provide evidential facts, legal facts and the history of the club for future reference and historical research. These practices need to compare with the preservation guides and manuals available for consultation.

Private archives: "A record that is not created in, or received by, a public office or local authority, and that is not a Minister's paper" (Archives New Zealand, 2006).

Public records: Are "records providing evidence of the business activities of persons or agencies exercising public office" (Kennedy \& Schauder, 1998, p.298).

Records continuum: "The whole extent of a record's existence. Refers to a consistent and coherent regime of management processes from the time of creation of the record through to the preservation and use of records as archives" (Kennedy \& Schauder, 1998, p.299).

Recordkeeping: "Making and maintaining complete, accurate and reliable evidence of business transactions in the form of recorded information" (Kennedy \& Schauder, 1998, p.299).

Club: An organization which is made up of members with the same interest, who meet to exchange ideas, participate in competition against another club with the same interest and to mix socially. "An association dedicated to a particular interest or activity" (The Oxford English Dictionary, 2009).

Volunteer: A person within the club structure who takes on a position to help organize and run the club in an ordinary manner without being paid for their time. "A person who works for an organisation without being paid" (The Oxford English Dictionary, 2009). 


\subsection{Theoretical Framework}

This research project examined how clubs go about the recording and maintaining of their records. Frank Upward (2000) developed a model for the records continuum drawing upon traditional archival science. It brings together both record management and archives administration. This continuum model comprises of four dimensions (from creation to becoming an archive) which forms the basis on which the interview questions are written.

1. Create: How are the records first created and is all the information recorded correctly? Are there templates which can be used so that a standard of presentation and capture can be contained?

2. Capture: Where are the records captured (into a recordkeeping system)? This system will show what records have been created.

3. Organise: The records are stored correctly so that they are available to all club members.

4. Pluralise: The records need to be accessible and able to be used or viewed by a wider audience, for example, the local community and not just club members. These records could be deposited with a local community archive, for example the local City Council library. Archives New Zealand has a publication The Directory of Archives in New Zealand - Nga Pae Mahara which lists community archives and their holdings in New Zealand.

5. Also the National Register of Archives \& Manuscripts [NRAM] is another register of community archives and their holdings.

\subsection{Research objectives}

- To establish the extent to which appropriate practices with respect to archival records are being carried out by rugby clubs. 
- To investigate ways in which clubs can improve their practices.

\subsection{Limitations and Delimitations}

\section{Limitations}

As the researcher resides in the Wellington area and the method of research is face to face interviews the research could only be practically conducted with rugby clubs within the Wellington region. This limits the findings to Wellington only and these results cannot be applied to rugby clubs throughout New Zealand.

\section{Delimitations}

The study targeted rugby clubs only. The answers supplied by the respondents depended on how they interpreted the questions asked.

\subsection{Human Ethics}

As the research involved contact with human subjects and to comply with the Victoria University Human Ethics Policy as well as the Privacy Act 1993 an application for approval to study was submitted to the SIM Human Ethics Committee on 19 March 2009 and the application was accepted on 31 March 2009.

\subsection{Conclusion}

This chapter has established the background and the need for this research. There are a further four chapters as follows:

- Chapter Two is the literature review which examines what relevant literature there is available on the topic. 
- Chapter Three shows the procedures and steps taken to collect and analyse the data received.

- Chapter Four breaks down the results question by question.

- Chapter Five summarise the whole research and makes recommendations of what can be done with the results. 


\section{Chapter Two: Literature Review}

\section{Introduction}

In rugby there is a term "grassroots rugby". This is where New Zealand rugby has its beginnings and it is the first place where activities of a rugby player commence at the local rugby club. These first activities should be documented and recorded so that rugby can celebrate its heritage in the future.

There is a small selection of literature available outlining the failures of clubs to maintain their records and prevent record practice disasters. There are places where preservation information can be located (sometimes in great detail) but this information does not always flow down to those volunteers who create and maintain the club records. This literature review will consider literature relating to archives, recordkeeping practices and preservation.

\subsubsection{Archives}

Sue McKemmish a professor of archival systems at Monash University, Australia, writes in her chapter of the book "Archives: Recordkeeping in Society" (2005 pp 1-15) that groups such as societies need people to store the memory as evidence of an event. The chapter stresses that the memory should be stored correctly and in the case of photographs, documentation should be attached, and there should be a record of where the photograph is stored so that if it changes hands the next person in the chain will not add their own caption and create a whole new story and change the evidential value of it. This follows the create and maintain dimension of Frank Upward's records continuum model. Using a recent current event as an example McKemmish shows how a photograph can be moved around from one person to another and the caption and story changed to suit the owner at that point in time giving a distorted view of the actual event. McKemmish writes in this chapter "Authentic 
records when preserved in systems that maintain their integrity ensure that they cannot be altered or tampered with, contain information and related documents that link them to the acts and events which they document." (McKemmish, 2005, p.15). Having the right documentation to prove the fact is vital and in the case of one of the rugby clubs it has a roll of honour of six men who died in action in the Second World War. Recent further investigation is unable to locate evidence to confirm that two of these men went to war. Terry Cook, a leading Canadian academic, explains that "Archives...... are a source of memories about the past, about history, heritage, and culture, about personal roots and family connections, about which we are as human beings and about glimpses into our common humanity....., much more than that, they are about narrow accountabilities or administrative continuity" (Cook, 2000, p5). Cook goes on to write about evidence versus memory and the appraisal of the evidence to "help determine which records...... actually have long-term, enduring or archival value". He refers to Fact Sheet No.4, produced by the National Archives of Australia, "What are archives?" which states: "All archives are records, but not all records become archives". The explanation of this statement is that records created act as evidence of that transaction at that time of creation. Depending on the type of transaction and once the usefulness of that transaction has expired it can be appraised for its memory content and then kept as an archive.

With reference to the records continuum model by Frank Upward, Cook sees the continuum as having vision and theoretical integrity, saying it covers both evidence and memory as in the dimensions of the continuum. Referring to the continuum dimensions and looking at the first dimension of create, this is where the evidence is created and the record made. The second dimension is where the evidence is stored for future use. The third dimension is where appraisal of the record is processed and the record becomes an archive and memory. 
With the fourth dimension the archive and memory is made accessible in an institution for all to research.

There are several references in the article to how recordkeeping has been achieved in the past, with recordkeeping management being the task of record managers. The appraisal and care of those records which have become archives is the work of the archivist. Cook suggests these two positions will be merged into one as the record continuum theory is accepted and adopted as practice.

In the situation of the rugby clubs both recordkeeping and archival practices are carried out by the one volunteer creating a situation analogous to the recordkeeping continuum thinking.

By keeping the rugby archives we are looking at the evidence to be appraised to establish the memories of the achievements, mistakes and failings of those members of the community who were members of the club. These archives are documenting the sporting history of that local community and act as evidence in any histories which may be written. By preserving the club's history, clubs are assuring that their heritage and history will be part of the collective memory of the local community forever.

This memory is vital when a player achieves All Black status. Then the records can be referred to when writing up the playing history of that player.

\subsubsection{Recordkeeping practices}

Alan Smith, in his article "Core business for rail museum futures" asks "does the museum have an active records management programme? Are the records securely preserved?" In the history of rail, technology has changed dramatically often becoming obsolete and the records if they have been preserved and archived correctly give insight into the past. He then goes on to say "the reality is that a lot of core files, minute books, correspondence is just 
stashed away. There are horror stories of society archives being stored in a member's house or shed and there needs to be clear accountability for where items are stored and under whose control" (Smith, 1998). This leads to the assumption that clubs within New Zealand have not been carrying out archives best practice guidelines. Munro (2000), a practising historian with the Stout Research Centre, Victoria University of Wellington, wrote that he arrived at the Star Boating Club in Wellington one night to find the club's history and records had been boxed up into ten or so boxes. A valuable, if disorganized and neglected, set of records was removed from the storeroom which was needed for other purposes.

Clubs are particularly dependent on the good will of the office holders for the care of their records according to Dawson, Dodd, Roberts \& Wakeling (2004). There is a lack of guidance on managing records and those looking after the records also lack the professional skills required. The internet provides information on the preservation of records e.g. Library of Congress, Preservation http://www.loc.gov/preserv/presfaq.html but often this information is lengthy and volunteers have only limited time to spare. Volunteers are responsible for maintaining the records they create but are unaware of their legal responsibilities and although they are not required to comply with the Public Records Act 2005, this can be used as a guideline.

According to Richard Hall “the proper management of an organisation's records is a significant part of its activities and as years pass the evidential value of its archives steadily increases" (Hall, 2004, p.129). In the case of this research, the organisation's records are minute books, correspondence, rules of the club and their changes, and financial and policy records. The question needs to be asked as to whether in light of what Hall has stated volunteers really understand the importance of the holdings. Do they see keeping the archives as an inconvenience? Is there a problem of having to find somewhere to store them 
and what is the point if they will never be referred to again? Do they keep the financial records for at least seven years as required by the Income Tax Act 2007, as they should know they must comply with this legislation? The Public Records Act 2005 does not apply to clubs therefore why comply. The Archives New Zealand, General Disposal Authority (GDA/1), Human Resources requires personnel files to be retained for those staff who have received awards etc. This can be used as a guideline for clubs to retain records as who knows whether any club member will one day become famous? The volunteers need to be convinced that this exercise is important, is not too difficult and has already been achieved by some clubs. There are precedents where this has occurred. Smith (1998) has recorded that the rail museum took stock of their archival holdings and now has them lodged with a community archive available for access by all of the community.

\subsubsection{Preservation}

Managing and Preserving Community Archives, which is produced by the National Preservation Office of the National Library of New Zealand (2005) is an example of what guidance is available and is designed for amateur archivists and the small community archives. The content is in a basic layman's language easy to understand with helpful tips and good explanations on archiving practice and why it is important to preserve archives. The tips give an explanation of what will happen if it is carried out e.g. "Well-designed storage enclosures protect material from the adverse effects of light" This is a useful resource and the research project will investigate what use, if any, clubs have made of it. It provides guidelines on the appraisal process and is very clearly written and spells out the areas that should be kept and why. However, the General Disposal Authority, Human Resources and Personnel Records [GDA/1] issued by Archives New Zealand (2005) recommends that records relating to sports clubs be kept for seven years and then may be 
destroyed. This requirement, if adopted by clubs and by volunteers without archival knowledge, could encourage the destruction of historical and evidential records.

"Photographs enable a sense of belonging to a community, helping to construct imaginative geographies, shape collective memory and define cultural differences.” Richard Cox, a distinguished American archival commentator, goes on to say that "The creation of a record is an act of community" and to "Preserve records as this act is essential to sustaining a memory of humankind's knowledge, achievements and mistakes and failings" (Cox, R., 2005). This view once again falls within the recordkeeping continuum. By looking at an old rugby club photo there is so much recorded evidence and memory to inspect, examples being fashion, buildings, landscape, personal appearance and transport.

"Caring for Taonga - Photographs" produced by the National Preservation Office of the National Library of New Zealand (2006) is a well-presented guide on how to preserve photographs but there is no mention of what to do with those photographs already badly damaged by sunlight and bad handling practices.

A new way of preserving the records is digitization. Smith (1999) covers many of the questions on this subject. If a club was to digitise its photograph collection then members could have easy access, photographs could be displayed and the original photograph could be protected from further damage by reducing unnecessary physical handling and it could be stored away. Bansal, Kumari, Kumar, Singh (2005) take this discussion further asking should every item be digitised? Selection needs to be considered before taking on a major project. There should be a close look at why records should be digitised. Is it for preservation or access, or both? Who will benefit from this project? A point they do raise which applies to some of the clubs is that if a photograph is past the stage where it can be digitised and the negative can be located then this could be the tool for recreating what has 
already been damaged or lost. As they state "Preservation is the activity of protecting something from loss or danger." For some clubs this type of project would be financially well out of reach. There is not really an alternative if digitization is not an affordable option. Preservation of a photograph in protective wrapping limits its worth as an item of viewable archive material.

"Caring for your Theatre Archives" edited by Collier \& Graham (2005) is a manual designed especially for theatre archives. It is designed for those with no or very little archival knowledge. It has a chapter on preservation and conservation which is useful in that it provides measures that can be taken to prevent damage. For example the manual says "Do not put archives in unventilated cupboards". This comment can be applied very easily to some of the rugby clubs visited. The guide lists what the relative humidity should be. All items should be boxed to prevent damage from floods and fire. These suggestions can be applied to many different archives. The manual also goes into detail about appraisal and creating an actual archive which is not what this research is about therefore this limits its usage. It does not cover in detail how to create and maintain the records.

"Guidelines for Environmental Control in Cultural Institutions" (2002 Brown, S., Cole, I., Daniel, V., King, S., Pearson, C.) developed by the Heritage Collections Council, Australia gives good examples of how damage is being done to records. The article begins with the statement "It is generally accepted that the factors causing the most damage to cultural collections are temperature, relative humidity, light levels, air pollution, pests, mismanagement, mishandling and carelessness". All these factors can be found within the club environment. This article goes into detail on how sunlight actually turns paper yellow, and how dyes fade. It tells how temperature fluctuation and relative humidity play a big part in damaging records and it is these areas which need to be addressed to preserve the records. 
To get an understanding of how these things happen should enlighten those who are dealing with the records and how to go about putting preservation plans into practice. The article goes on to explain that it is the UV radiation in light which does the damage and light does more damage than temperature.

A resources guide "Preventive Conservation" produced by the Museum of New Zealand, Te Papa (2001) covers all the areas the research project looks at. It gives a description of the problem and how it is caused. It then suggests actions to remedy the problem broken into three parts. It describes an action for those with a high budget, for those with a low budget and provides good housekeeping suggestions. This is very direct and easy to follow and free to download.

A pamphlet produced by the Presbyterian Historical Society accessed online lists the causes of deterioration and then gives solutions to each problem.

The Storage Standard issued by Archives New Zealand (2007) lists the standard for storing records and can be used as a guideline but for many clubs the space required and the funds needed is well beyond their reach.

There is no specific literature about rugby club archives. The New Zealand Rugby Union does produce a best practice manual which gives instructions on how to run, organise and maintain a rugby club but this manual does not cover the process of recordkeeping. Sport and Recreation New Zealand [SPARC] have a Club Kit which provides tools to run a club with a section on writing the club history but again there is no advice on how to create or preserve the records to achieve this. This project will establish what is missing in terms of recordkeeping knowledge and the results can be utilised to develop literature in the form of a manual or guidelines in recordkeeping and archival practices for rugby clubs. 


\subsection{Conclusion}

There is little literature which deals directly with rugby archives. No literature could be found about rugby club volunteers. 


\section{Chapter Three: Research Design}

\section{Introduction}

When designing this project as qualitative research a plan was required to identify the procedures for data collection, who should be approached to participate and how the data collected was to be analysed.

This chapter show how each of these areas was approached.

\subsection{Methodology}

This project investigates what preservation and archival best practices are currently being used. To obtain the type of data, which show what is being done, the researcher used the interpretivist paradigm, "Investigation in natural settings of social phenomena" (Picard, 2007, p.11). That is, to investigate the subject with interaction between the researcher and the subject by observation in natural surroundings. This research took the form of a small indepth sample of the topic, studying the behaviour of individuals at the grassroots level of rugby in New Zealand.

The data was collected by observation of what archival practices are physically being carried out, speaking individually to those people involved in the rugby club and looking at what records have been created. The data was then analysed using a coding system providing the evidence required to give trustworthiness to the final findings. The project is not designed to solve the problem but rather to open up the nature of the problem for further investigation. The project needed to look at viewing the social and local history of the rugby clubs, looking at how things have happened, the role of the club in the local community and predicting what comes next. The project investigated and recorded what guidelines of best practices clubs 
have used in the past. It highlighted what knowledge the volunteers have of archives best practice and by conducting face-to-face interviews and observing the surroundings the true facts emerged.

\subsection{Procedures}

\subsubsection{Pilot interview}

A rugby club was contacted and asked to participate as the pilot study to evaluate the letter of information (appendix 4), information sheet (appendix 6), consent form (appendix 5), questions to be asked (appendix 7) and the areas to be observed by the researcher.

The interview took place to establish:-

- If the right questions were being asked.

- If further questions would need to be developed.

- How long the interview would take

All the above were important factors to ensure that the interview process would work well and that enough data would be collected to be able to produce a report of some meaning. As the rugby season is a busy time for the volunteers running the club it was important that the limited time they have to participant was used wisely.

The outcome from the pilot interview was that the letter, information sheet and consent form were received well. When conducting the interview care was needed to ensure that the interviewee do not divert from the original question and discuss the political side of the game and was not drawn into discussion about the Wellington Rugby Union. Probing about archival practices was needed to find out what the interviewee actually knew about archives and preservation in general so that it could be applied to the situation at the club. No real 
observation of the records could be made as the majority of records were held elsewhere and this situation may apply to other clubs. The pilot interview took forty five minutes. It was decided one hour for the interview at the other clubs would be sufficient.

\subsubsection{Collecting Data}

The researcher is the primary instrument for data collection. As Creswell (2002, p.200) states "It is the researcher who will identify the personal values, assumptions and biases at the outset of the research".

For this research project, the researcher went with an open mind not anticipating the outcomes from the visit. The purpose of the visit was to interview the club member responsible for the archives. The researcher asked open questions and observed in depth the surroundings and interpreted what, if any, best practice guidelines were being observed. Six pre-arranged site visits were conducted as well as a pilot visit this making a total of seven clubs. These visits consisted of an interview and observation. A recording of the interview was made (with the consent of the interviewee).

A set of open ended questions were prepared for the site visit starting with easy questions so as to build up a comfortable relationship. The opening question was "what role did the interviewee hold within the club structure". The interviewer at times probed during the questions to get more information e.g. "Can you tell me more about that?" The open style of questions allowed the volunteer to talk and give information freely.

At the same time as the questions were being asked the observation mark off sheet was filled in and some further notes made under the following headings. 
1. Create: for what purpose are the records created? What information is captured?

2. Capture: What if any system is used to capture the records. What information is captured?

3. Organise: How are the record filed and stored, can members of the club access them easily?

4. Pluralise: Are the archives being deposited with a local community archive? Are the records able to be accessed by anyone?

The analysing of data collected began from the first interview as soon as possible after the site visit. The interview notes were transcribed verbatim by the interviewer and coded while still fresh in the mind. Also the notes from the observations made were recorded and a note made of how freely the volunteer gave the information. Where necessary, questions were altered before the next interview.

\subsubsection{Population and Sample}

There is a total of 14 Rugby Unions in New Zealand, comprising 328 clubs. For the purpose of this project and due to time constraints, to visit all clubs within New Zealand would not be practical or possible therefore a sample approach was taken. A postal survey to all clubs was not considered as clubs are run by volunteers and the survey may not be given to the right person to complete or it might just be discarded. There was no certainty that the person answering the questions would be the person with the appropriate knowledge of this area. As the researcher lives in the Wellington area and the project required site visits it was decided to concentrate on this area. There are eighteen clubs that form the Wellington Rugby Football Union. The geographical area covered by the WRFU extends from central Wellington as far north as Upper Hutt and Porirua. 
A letter was sent to the Wellington Rugby Union, (appendix 2). This outlined the research to be undertaken and the possible outcome. The WRFU confirmed their approval by correspondence (appendix 3).

The seven clubs chosen provided a representative sample within the area. They covered a wide range of formation dates with two over 100 years old. Two clubs formed from amalgamation, one that will be celebrating 100 years in the near future and two young clubs.

Interview dates and times were confirmed with clubs and upon arrival the interviewee was given the letter, information sheet and consent form which was signed before the interview took place.

One club did not respond to the invitation to participate and to keep the total at seven another club was approached. Appendix 1 is a full list of clubs which are members of the Wellington Rugby Football Union.

\subsubsection{Data Analysis}

Sogunro (2002, p.3-4) quoting Creswell (1994) defines qualitative research. "It is a collection of extensive data on many variables over an extended period of time, in a naturalistic setting, in order to gain insights not possible using other types of research". In other words it is research where people, situations and events are observed at their place of origin. This is how the interviews were carried out. The data collected from the interviews was looked at, extracted and summarized into categories to form a theme from which a report can be developed. It showed the areas of concern and where the next step in the process can be made.

After each interview the tape was transcribed verbatim. A folder was created for each question and as the interviews were processed each club's answers were placed in the 
appropriate folder. Each question had a main table drawn up with numbered answers and a second table with the clubs' names. The clubs' answers were coded in alignment with the main table into yes, no or don't know and the totals entered into the main table to show how the clubs responded. These responses make up the results recorded in chapter 4 .

\subsection{Conclusions}

The pilot interview worked well and adjustments were made in the way the questions would be asked to prevent straying from the topic. The time allowed for the interviews was sufficient. The time taken to transcribe the pilot was six hours which meant that subsequent interviews would have to be spaced to allow for transcription between them. The coding system should give an even spread of good and bad examples and provide enough data to produce a result from which action can be taken. 


\section{Chapter Four: Interview Results}

\section{Introduction}

Seven clubs agreed to participate in the research project and all are interested in what the results will show. Each club was asked the same questions and where possible the storage of the records was observed. All clubs agreed that photographs could be taken of their archives.

Each club has been given a code from RFC1 to RFC7. These codes will be used when quoting from the transcript or referring to what has been observed so that a link can be identified between the answers.

Each question has been broken down into sections so that the data collected from each club can be slotted into the appropriate section. This will then give a breakdown by number of how well the archives of the clubs are being looked after.

There was a total of 18 questions asked and the results follow with an explanation and a table.

\subsection{Results}

\subsubsection{Role in the club}

Table 1 shows that those who participated in the interview were mostly those who hold senior positions in the club. It is this group of volunteers who are responsible for the creating of records within the club. The position of president of a rugby club is generally one for prizegivings and making presentations on behalf of the club. It is the chairman who heads the committee and controls meetings. Next in order of importance are the secretary and the treasurer. A life member will generally be a person who has in the past been chairman, secretary or treasurer. Of the seven clubs interviewed two clubs had more than one person answering the questions which demonstrates the willingness to participate. 


\begin{tabular}{|l|l|}
\hline President & 0 \\
\hline Chairman & 4 \\
\hline Secretary & 1 \\
\hline Treasurer & 1 \\
\hline Life Member & 2 \\
\hline Committee Total & 11 \\
\hline & 3 \\
\hline
\end{tabular}

Table 1: Role in the club

\subsubsection{Create}

\subsubsection{Minutes of the club}

The minutes of a club are a written account of what has been discussed at a meeting. It is this written document which preserves and retains the memories of facts and events as they have taken place over the years.

Minute books are used as a resource by historians, genealogists, students and the club itself to confirm what has happened in the past for example when determining why an event is being held and the history behind that event. It is in the minutes where a correspondence register is kept. The minutes show the make-up of the committee and can help give an understanding of the social context of the day. The minutes show how a club has progressed and the first set of minutes will list the intentions of the club and why the club was formed.

Table 2 indicates that clubs are keeping their minutes in one form or another but in the case of the seven interviewed only two clubs were aware of what archival and preservation practices they should be putting in place for their minutes.

Five of the clubs interviewed said that they had a complete set of minutes from the date of conception starting with bound hard covered handwritten books, to typed minutes saved in a 
minute file. The remaining two clubs have a complete set of those minutes typed and printed and saved in a file. It is the original books that have been lost. One club (RFC6) goes that little bit further and glues the printout of the minutes into a numbered minute book. Once glued in they cannot be changed or removed.

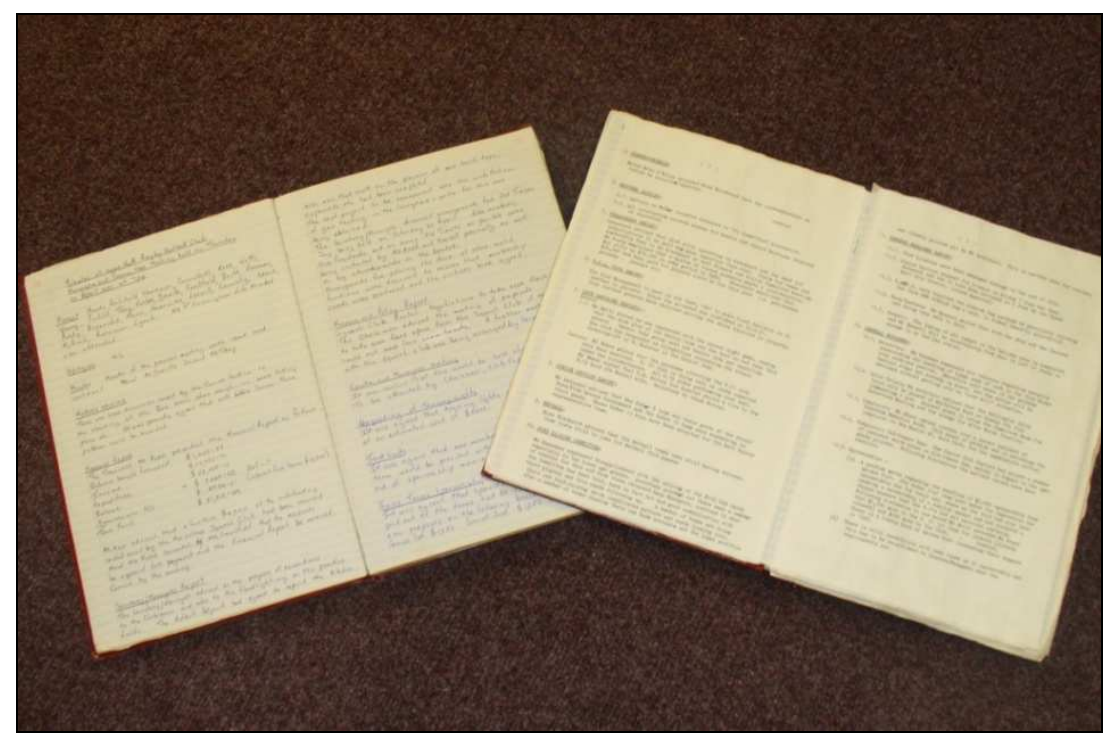

Fig1: The handwritten and glued in minutes in the minute books has kept continuity in the archiving of minutes

The downside of printing minutes and filing in a minute file is that they can be removed or changed without anyone knowing and if any investigation took place you would need to ask how accurate the printed set is. If the minutes are in a folder what systems have been put in place to make sure no minutes are removed?

When minutes were written in the minute book it would not be until the next meeting when they were read out that the committee could confirm they were correct. Now once the secretary has typed them up they can be distributed for comment. All clubs interviewed said that they distributed the minutes to the majority of the committee via e-mail. In the case of five of the clubs because some of the committee do not have computers the minutes were printed out and delivered. 
All clubs reported saving copies of minutes on home or workplace personal computers, but RFC6 use a club computer for this purpose. The problem with saving to a work or home computer is this information can be lost when a person leaves their employment or at home the computer could be stolen or the system crash.

When inspecting where the minute books are kept four of the clubs thought by having the books in a cupboard was sufficient. Of these four, one club at least had them in a box but the remaining three were loose on shelves in the cupboard. Their knowledge of storage standards is limited and their awareness is recorded in the Storage Standard question.

The interviews also showed that clubs have in the past not kept track of their minute books. Upon the death of a member from (RFC2) club, the family without thinking threw away all the minute books which were in that member's house. (RFC6) have no idea where 50 years of their junior section minute books are, they do know they exist but no one knows who last had them. 


\begin{tabular}{|c|c|c|c|}
\hline & Yes & No & Don't know \\
\hline Maintained in a minute book & 1 & 6 & 0 \\
\hline Typed up, printed and filed in minute file & 7 & 0 & 0 \\
\hline Saved in home or office PC & 7 & 0 & 0 \\
\hline Saved in club PC & 1 & 5 & 1 \\
\hline Distributed by e-mail & 7 & 0 & 0 \\
\hline Distributed by hand or posted out & 2 & 5 & 0 \\
\hline $\begin{array}{l}\text { Does the club have a complete set of } \\
\text { minute books from date of inception? }\end{array}$ & 5 & 2 & 0 \\
\hline Storage of minute books -boxed & 1 & 6 & 0 \\
\hline Storage of minute books - shelved loose & 3 & 2 & 1 \\
\hline Storage of minute books - cupboard & 4 & 3 & 0 \\
\hline Storage of minute books - special room & 2 & 5 & 0 \\
\hline Stored in temperature controlled room & 0 & 7 & 0 \\
\hline Lodged with archival institution & 1 & 6 & 0 \\
\hline
\end{tabular}

Table 2: How the minutes are created and maintained

One club which had a space problem looked into what to do with their minutes and RFC6 have lodged their older books with an archival institution keeping only the minutes of the last four years at the club.

\subsubsection{Correspondence of the club}

How is the correspondence of the club processed?

As with most organisations correspondence is received on a regular basis with some of it not being relevant for the running of the club. Several different types of advertising is received from those trying to establish themselves within the club along with the normal accounts, financial, letters from members and important correspondence from the WRFU (contracts for 
signing). The advertising correspondence could be destroyed. The Wellington Rugby Football Union are now sending most mail electronically but for important letters a paper record will also be sent for filing. What needs to be taken into consideration is what happens to the electronic mail which is received by the different members of the committee.

As table 3 show all clubs handle both electronic and paper correspondence. Five out of the seven have a selective system in place and destroy mail that is not relevant. In the majority of interviews it was revealed that the secretary handled the correspondence. Because only one secretary participated in the interviews this answer could be questioned. Not one club knew how mail, especially electronic, received by other committee members was being handled.

When asked about old correspondence three clubs did not know what happened to it and the other four either kept it all or destroyed it. One club tied it up with string and put it in a cupboard.

The research did not determine whether clubs were taking a responsible approach to correspondence received.

\begin{tabular}{|l|c|c|c|}
\hline & Yes & No & Don't know \\
\hline Mixture of both e-mails and letters & 7 & 0 & 0 \\
\hline Selective e-mails printed off and filed & 5 & 0 & 2 \\
\hline $\begin{array}{l}\text { Correspondence mainly dealt with by } \\
\text { secretary }\end{array}$ & 5 & 2 & 0 \\
\hline Selective correspondence filed & 5 & 0 & 2 \\
\hline $\begin{array}{l}\text { Correspondence received by others, } \\
\text { either electronic or paper, filed in } \\
\text { main folder }\end{array}$ & 0 & 1 & 6 \\
\hline Old correspondence kept & 4 & 0 & 3 \\
\hline
\end{tabular}

Table 3: Correspondence 


\subsubsection{Financial Records}

As with all organisations which have financial responsibilities all clubs must comply with legislation. The main one is the Income Tax Act 2007 and under this legislation financial records are to be retained for seven years.

In the financial area as Table 4 shows all clubs were aware of legislation but when asked if there was a destruction programme in place only two clubs had this. Three clubs were unsure of what they actually had and two clubs had no idea at all. The reason for this could be that when asked how the financial records were stored five clubs did not know because the records are stored at the treasurer's house.

All clubs must present to the Annual General Meeting a set of audited accounts. As all clubs are Incorporated Societies and should be registered with the Incorporated Societies Office part of their legal responsibility is to lodge an audited set of financial accounts with that office each year. If this is not complied with they could be struck off the register. A check was done on the Incorporated Societies website which showed six clubs are registered and one has been struck off. If correct record keeping practices were in place this should not happen.

\begin{tabular}{|l|c|c|c|}
\hline & Yes & No & $\begin{array}{c}\text { Don't } \\
\text { know }\end{array}$ \\
\hline Aware of the Income Tax Act 2007 & 7 & 0 & 0 \\
\hline Know to keep records for seven years & 7 & 0 & 0 \\
\hline Records stored in binder & 2 & 0 & 5 \\
\hline Records destroyed after seven years & 2 & 3 & 2 \\
\hline
\end{tabular}

Table 4: Financial Records and legislation 


\subsubsection{Preservation Practices}

The main area of preservation that affects the archives of the clubs is the damage that can be inflicted by sunlight, poor lighting, storage and temperature, and by pests and neglect.

The first questions to be addressed were whether clubs knew of preservation practices and whether they had any archival practices in place. Four areas were examined in depth to get a better understanding of how the clubs were dealing with preservation. Each area has its own breakdown and explanation.

The areas examined are:

- Photographs

- Trophies

- Club Jerseys

- Memorabilia

When asked if they were aware of preservation practices four clubs agreed that they were aware that some form of preservation should be put in place but only one club, RFC3, had taken it further. This club sought advice from the conservation department at Te Papa (National Museum of New Zealand) and this will be highlighted in each of the extended answers. Another club, RFC6, has just completed renovations and has a room set aside to store items but was in the process of seeking advice on the best way to put some preservation practices in place.

Table 5 shows that six of the seven clubs interviewed were aware of the damage caused by sunlight and fluorescent light but felt that as items were not in direct sunlight not much damage could be done. One club, RFC4, thought that as fluorescent lights were only on for a short period of time this would not cause any damage. Rugby club premises are utilised mainly during the winter when the season is in force and the actual club rooms are mainly 
used on a Saturday for about six or seven hours. RFC4 noted that one form of damage has now been eliminated with smoking banned inside the club rooms. When making observations of the club rooms during the day, four of the clubs appeared to be rather dark upon entering with very few windows so the need for lighting was obvious. There were three clubs which had windows which let sunlight in but photographs on the walls were not in the direct line of sunlight.

When asked if the club was carrying out preservation practices six clubs answered no but when asked more directly on what was being done in the particular areas it became clear that clubs were putting some form of preservation into practice without really knowing it.

\begin{tabular}{|l|c|c|c|}
\hline & Yes & No & Don't know \\
\hline $\begin{array}{l}\text { Aware of preservation } \\
\text { practices }\end{array}$ & 4 & 3 & 0 \\
\hline $\begin{array}{l}\text { Carrying out preservation } \\
\text { practices }\end{array}$ & 1 & 1 & 0 \\
\hline Seeking advice on what to do & 2 & 1 & 4 \\
\hline $\begin{array}{l}\text { Aware of damage sunlight } \\
\text { does }\end{array}$ & 6 & 1 & 0 \\
\hline $\begin{array}{l}\text { Aware of damage fluorescent } \\
\text { light does }\end{array}$ & 6 & 1 & 0 \\
\hline
\end{tabular}

Table 5: Preservation awareness

\subsubsection{Photographs}

As the saying goes "A picture says a thousand words".

When looking at photographs from the first team when the club formed to the present day there is so much to take into account. Things to look for include the style of the playing jersey, the hair fashion, and whether the men have facial hair. What are the coach and team manager wearing? If the photograph has been taken outside what is in the background and surroundings? Perhaps the original club rooms have now been pulled down and replaced. 
The photograph might show empty fields which are now covered in houses. There is likely to have been a lot of community growth and development and photographs taken over the years will show this. People like to look at photographs for the above reasons but they also like to try and identify someone within the photo, so to have the names of the players and others shown with the photograph helps with identification of the players.

All clubs take pride in displaying their photographs but as Table 6 shows only three clubs have taken action to preserve some of their photographs. All clubs seem to be aware of the damage being caused to the photographs by exposure to sunlight, fluorescent light and human handling but only three clubs have made an attempt to rectify the problem. There was a general understanding that because the clubrooms are not open daily the amount of exposure to lighting will have little or no effect and as the photos are not in the direct line of windows the sunlight will also have no effect.

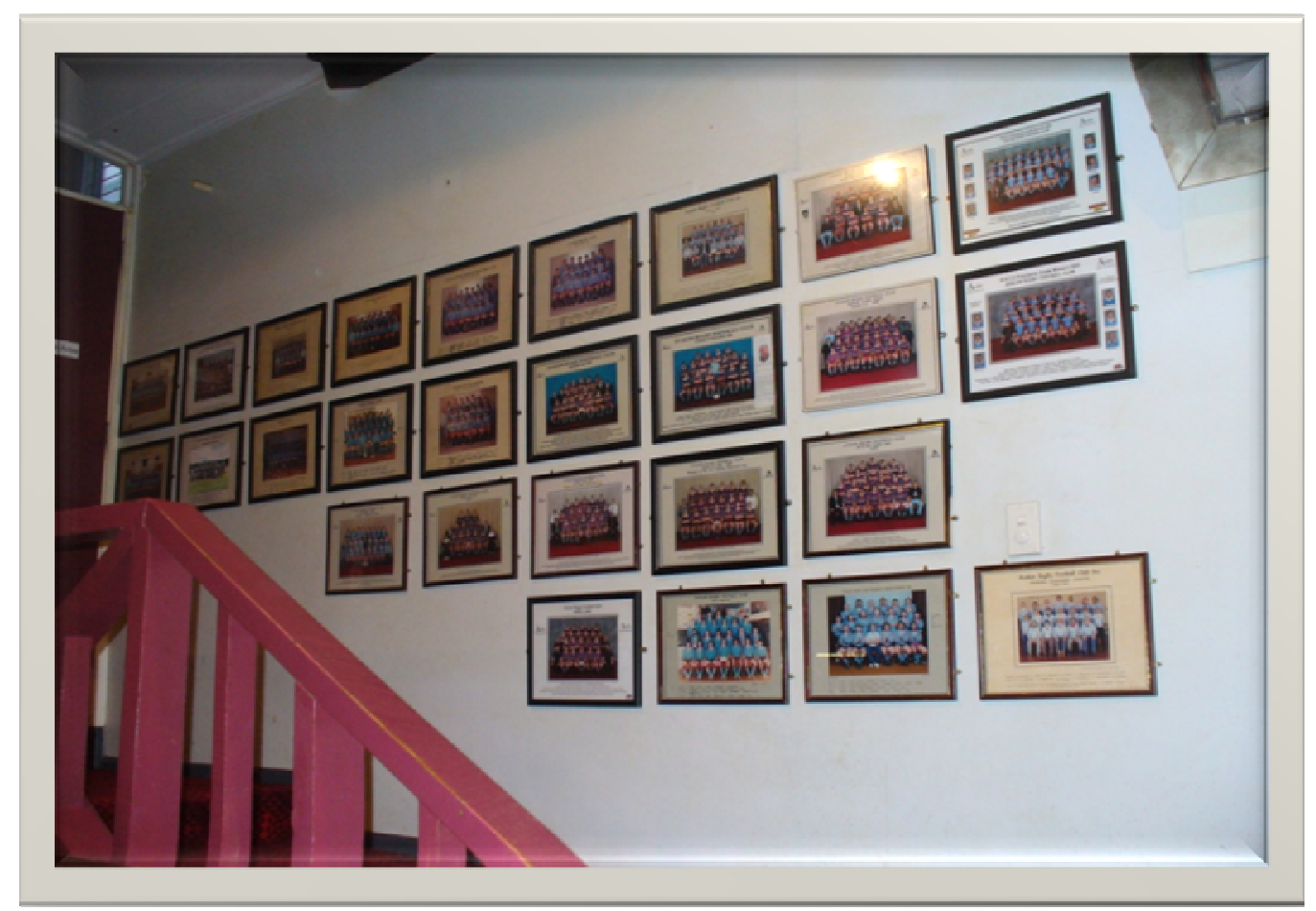

Fig 2: Team photographs on the wall of the club rooms 


\begin{tabular}{|l|c|c|c|c|}
\hline & Yes & No & Don't know & N/A \\
\hline $\begin{array}{l}\text { Aware of damage that } \\
\text { can be created }\end{array}$ & 7 & 0 & 0 & 0 \\
\hline $\begin{array}{l}\text { Action taken for } \\
\text { preservation }\end{array}$ & 3 & 4 & 0 & 0 \\
\hline $\begin{array}{l}\text { Complete set of } \\
\text { winning team } \\
\text { photographs }\end{array}$ & 3 & 2 & 2 & 0 \\
\hline Photographs on wall & 7 & 0 & 0 & 0 \\
\hline Photographs loose & 5 & 2 & 0 & 0 \\
\hline $\begin{array}{l}\text { Photographs boxed and } \\
\text { catalogued }\end{array}$ & 1 & 6 & 0 & 0 \\
\hline $\begin{array}{l}\text { Duplicate photographs } \\
\text { created }\end{array}$ & 1 & 6 & 0 & 0 \\
\hline $\begin{array}{l}\text { Acknowledgement of } \\
\text { photographs presented }\end{array}$ & 3 & 3 & 0 & 1 \\
\hline $\begin{array}{l}\text { Original first team } \\
\text { photograph on wall }\end{array}$ & 3 & 2 & 2 & 0 \\
\hline
\end{tabular}

Table 6: Team photographs

One club had displayed its collection of photographs on the walls of two staircases and along a hallway. Some photographs were not in frames. Both staircases were in direct sunlight. People could touch the photographs therefore the fingerprints were leaving perspiration and other harmful material. Fig 3 shows photographs in different stages of destruction with one now no longer able to be identified due to careless handling and display. When this was pointed out the club took down all the photographs and is seeking advice on what the next step towards restoring and preserving the photographs should be. 


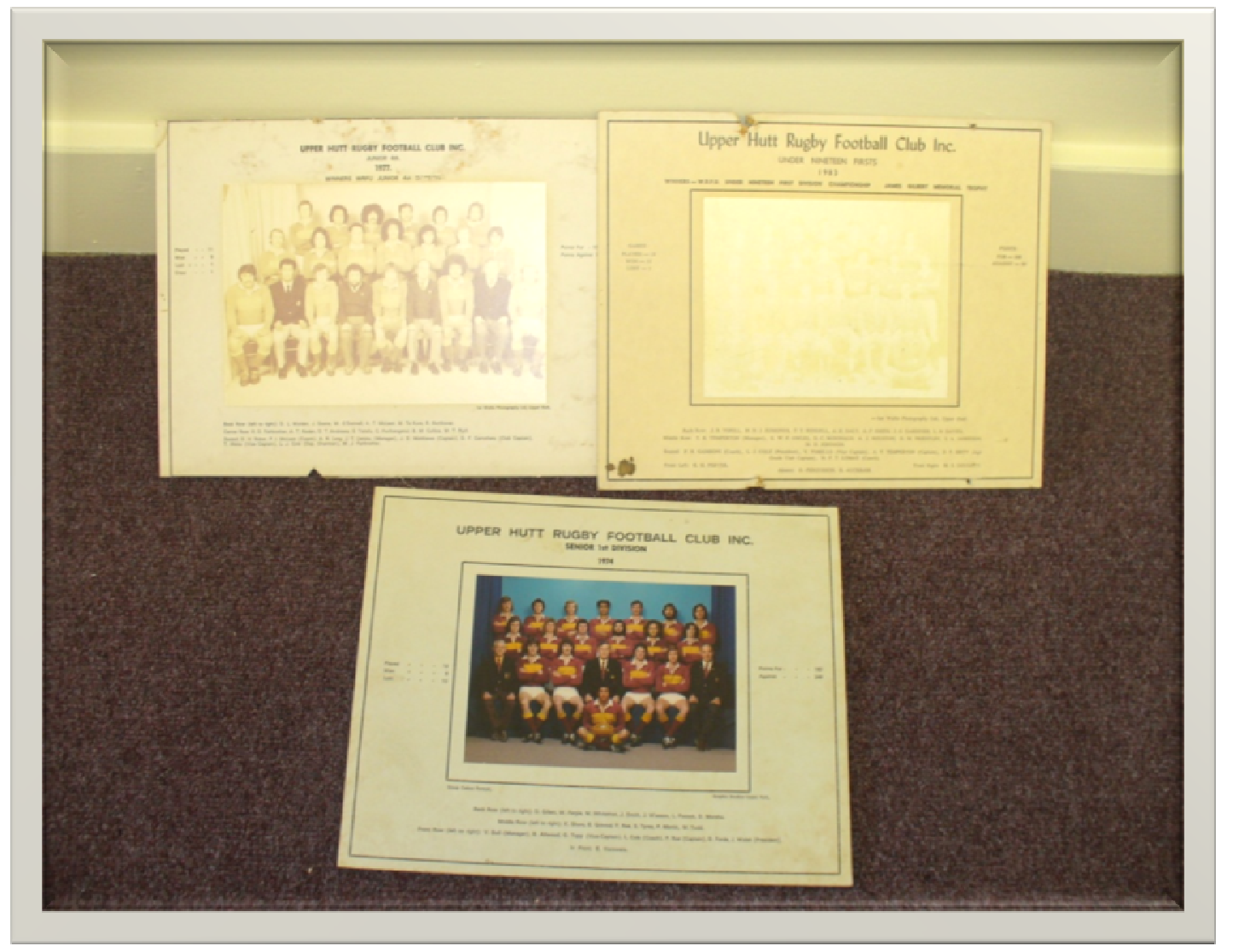

Fig 3: The effects of bad wall mounting and sunlight on team photographs

Table 6 shows that clubs are unsure of what to do with excess photographs. RFC4 said they had "bucket loads" of boxes of photos. RFC7 has their excess photographs stacked up behind a cupboard. RFC6 found a collection of photographs all loose in a cupboard in the bar. RFC2 has a box of photographs stored at a club member's house. Only one club has photographs boxed and catalogued.

Two clubs talked about digitisation of their photographs but were unsure of the best way to approach this. This could take some time as finding the funds for such a project is a big problem. RFC4 when preparing for their centenary microfilmed all the photographs up till that date. 
One club has already done something similar by locating a duplicate photograph and having special flip flop holders made up and the duplicate photograph inserted. The other benefit of this type of system is it does not take up all the wall space of the club and all photographs are there for inspection.

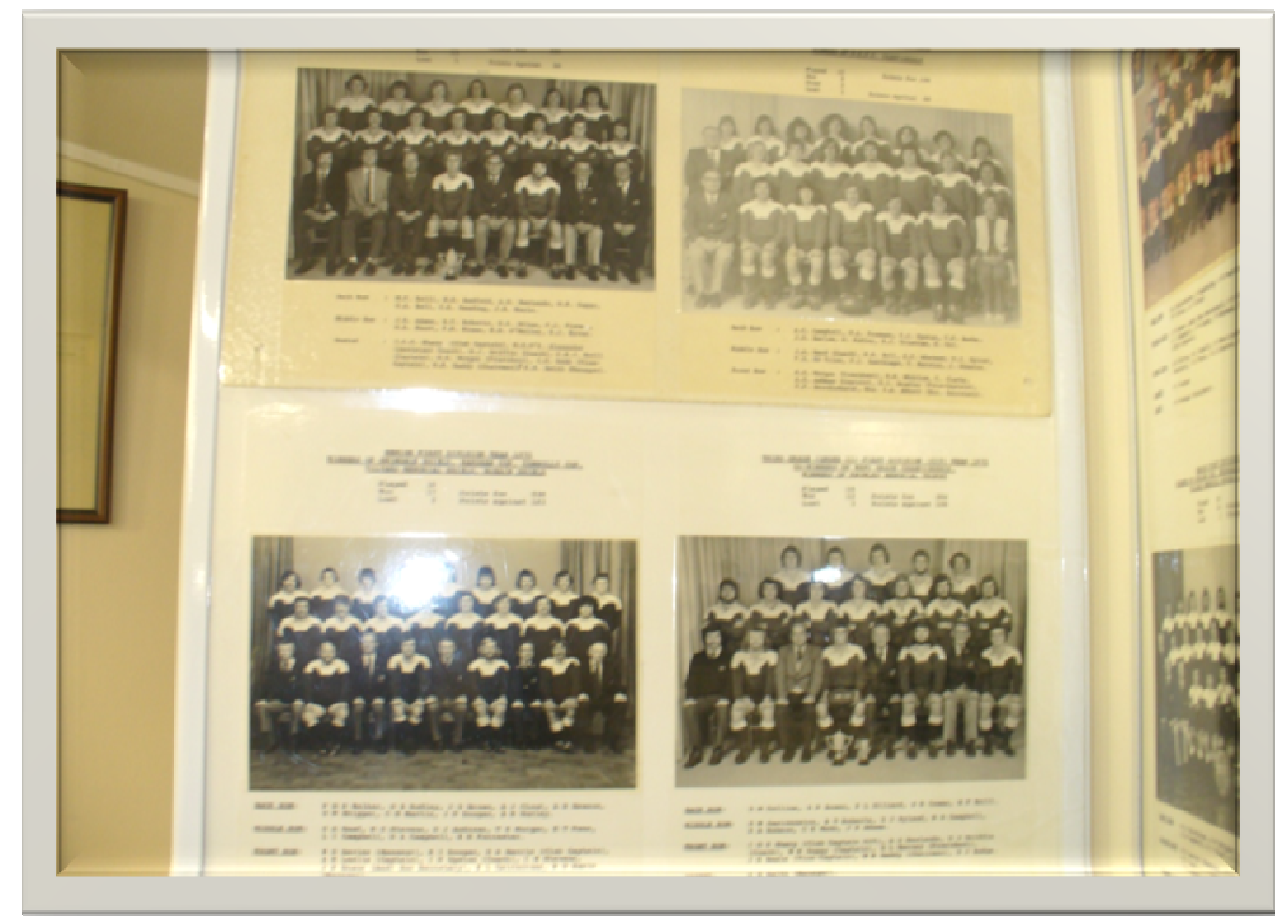

Fig 4: Flip flop holder with four photographs 


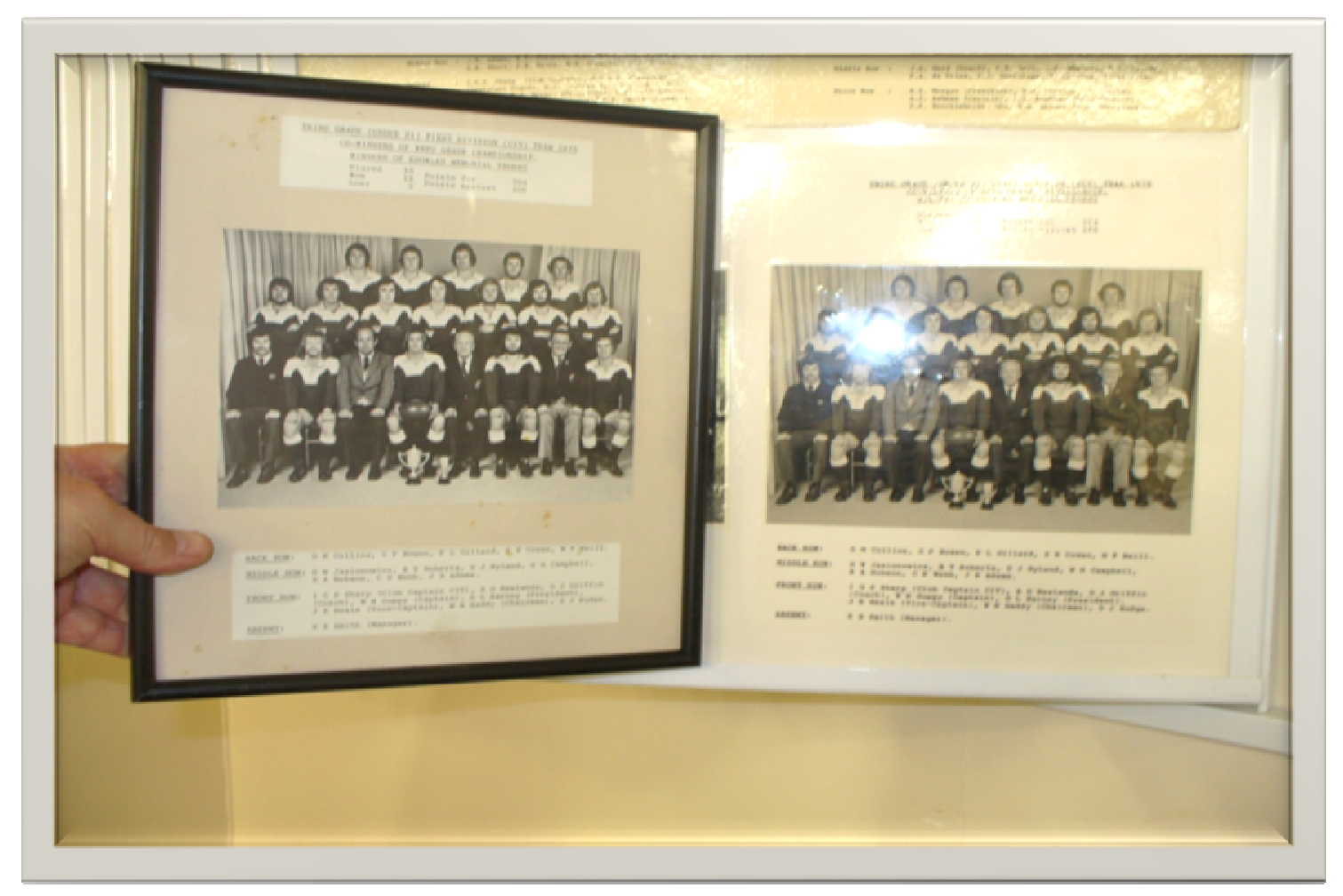

Fig 5: The original photograph alongside the duplicate in the flip flop holder

Acknowledging those players who have achieved All Black status is a high point for any club but only two clubs have given these players the honour of having a photograph on the wall. Three clubs have not had players reach All Black status. Another acknowledgement is to have a photograph of all life members on display as well as of any club member who has achieved national honours and RFC3 has done this with their member who was awarded the Victoria Cross in World War One. 


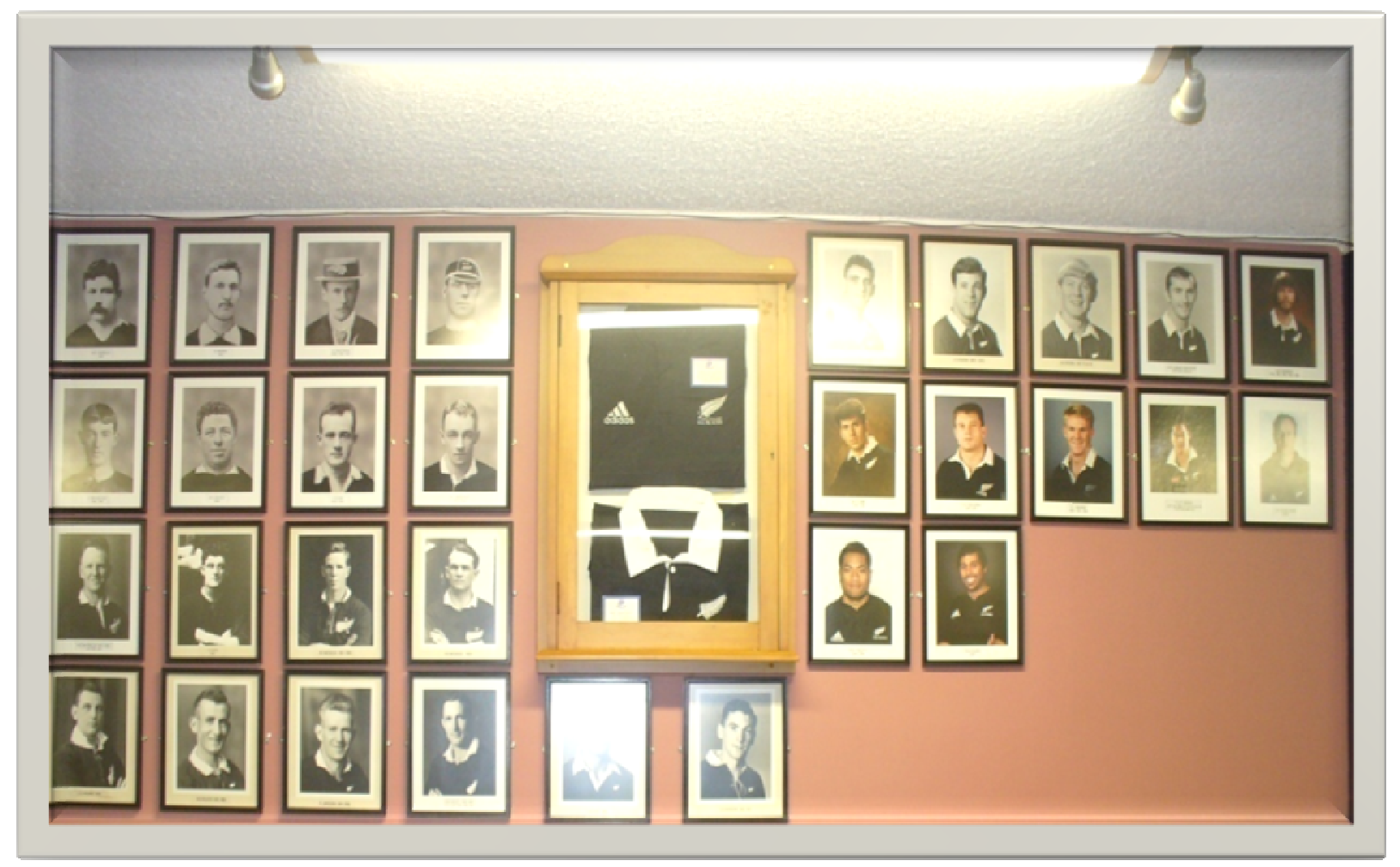

Fig 6: One club's All Black acknowledgements

Three clubs had team photographs which were framed but still exposed to all the elements already discussed. Several of these photographs were over 100 years old and if no copies have been made there is a lot of history which could be lost if action is not taken to preserve these images. 


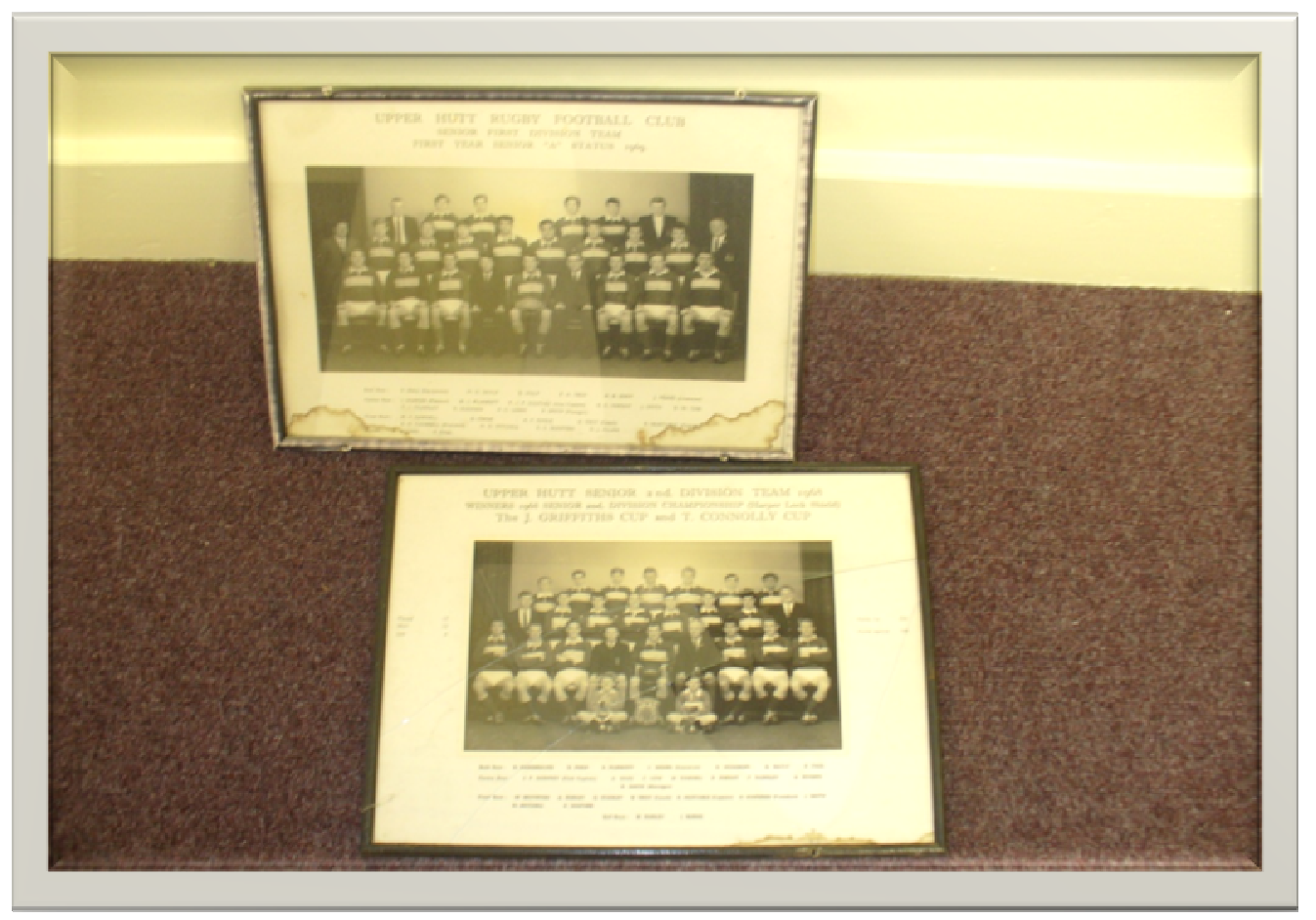

Fig 7: Poor storage of photographs causing glass broken in bottom photo

\subsubsection{Trophies (cups)}

Every year at the end of the season a club will have a prize giving where teams and individuals are recognised for their achievements and are presented with a trophy or a cup. A cup is either donated or purchased and may be named after some person from within the club who has given special services. For example the Ewart Memorial Cup was named after the first chairman of a club. As the years progress those who the cup has been named after will pass on and for new members of the club this name will have no meaning. It is important therefore that the history behind each trophy is recorded. Also each year the recipient's name is usually engraved on the cup making the cup a history within itself.

These trophies need to be protected from theft and loss. Trophies should be kept in a locked cupboard and removed only for prize giving. In the past trophies were given to the recipient to retain until the next prize giving but if the recipient moved away the cup would be lost. To 
prevent this from happening most clubs when presenting the cup will give the recipient a small replica to take away and keep, retaining the original cup securely in the club premises.

It should be noted that as the cups are generally made of silver the older the cup the more valuable as they were sterling silver whereas the more recent ones are silver plated.

The reason for awarding the cup sometimes disappears and all clubs have cups which they no longer recognise at prize giving.

As table 7 shows all clubs have taken archival steps in the preservation of their trophies by keeping them in locked cupboards and issuing a replica at prize giving but only three could provide the history behind each cup and two clubs did not have a record of all past and present trophies.

\begin{tabular}{|l|c|c|c|}
\hline & Yes & No & $\begin{array}{c}\text { Don't } \\
\text { know }\end{array}$ \\
\hline On display in cabinet & 7 & 0 & 0 \\
\hline $\begin{array}{l}\text { A history kept of each } \\
\text { trophy }\end{array}$ & 3 & 4 & 0 \\
\hline List of all trophies & 1 & 4 & 2 \\
\hline $\begin{array}{l}\text { Hand out replica trophies at } \\
\text { prize giving }\end{array}$ & 7 & 0 & 0 \\
\hline
\end{tabular}

Table 7: Club trophies 


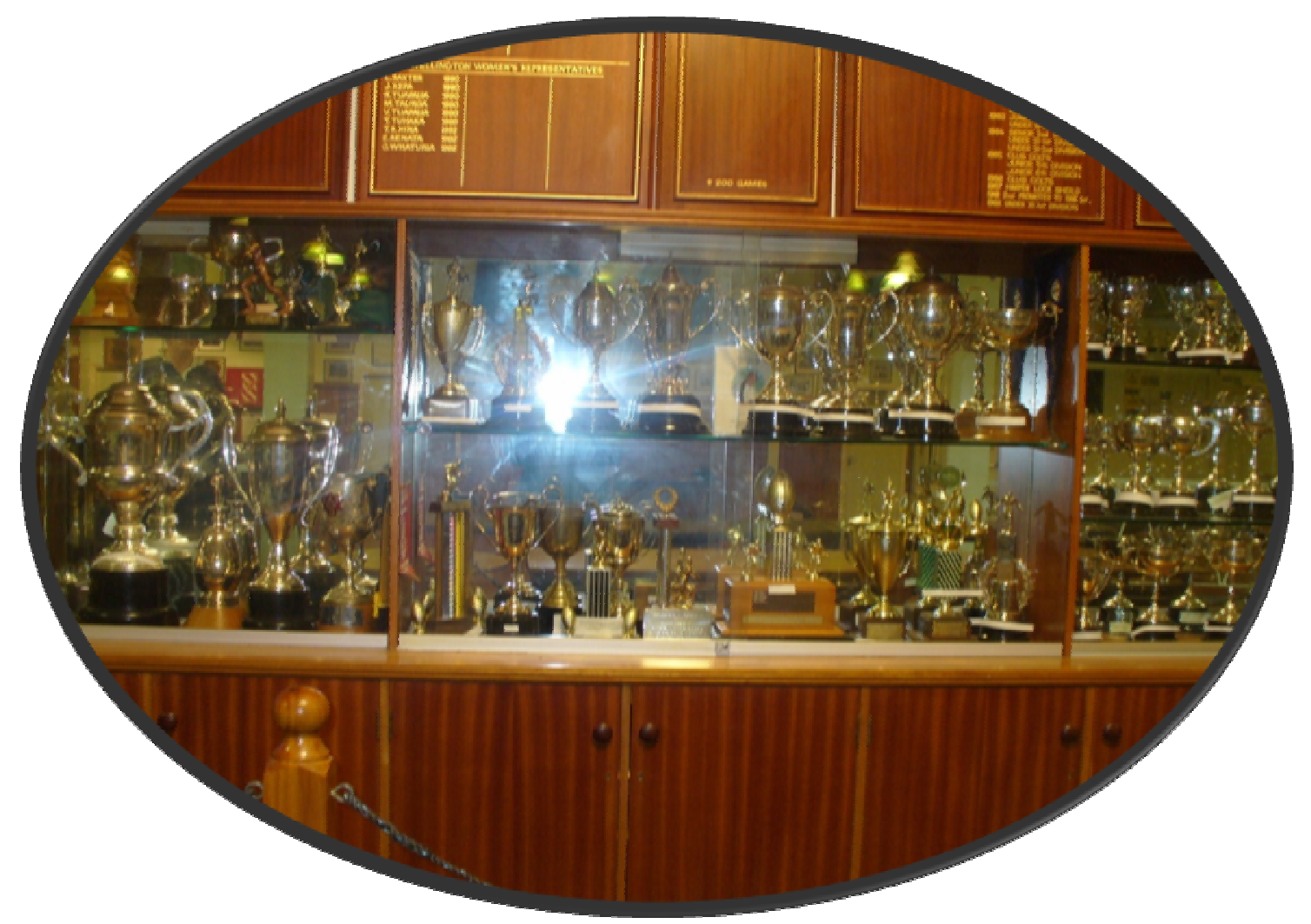

Fig 8: Trophies in display cabinet

\subsubsection{Club Playing Jerseys}

Each club has a distinctive playing jersey for the team to wear in competition games. Over time the style and fabric will change as fashion trends change. The style of jersey in a photograph can help identify the date the jersey was in use.

Table 8 Shows that the majority of clubs have continued with the original style of jersey with the fabric changing to a more modern polyester mix. The original jerseys of two clubs were laced up in the front which was the style in the early 1900's. 


\begin{tabular}{|l|c|c|c|}
\hline $\begin{array}{l}\text { Has the jersey } \\
\text { changed over } \\
\text { the years? }\end{array}$ & 2 & 4 & No \\
\hline $\begin{array}{l}\text { Do you have a } \\
\text { complete set } \\
\text { of jerseys? }\end{array}$ & 4 & 2 & 1 \\
\hline
\end{tabular}

Table 8: Club jerseys or playing strip

One club which was formed from two clubs merging has kept the two previous clubs' jerseys in a display cabinet. This is a good way to show what was but the lighting used needs investigation to ensure no damage is being done to the fabric.

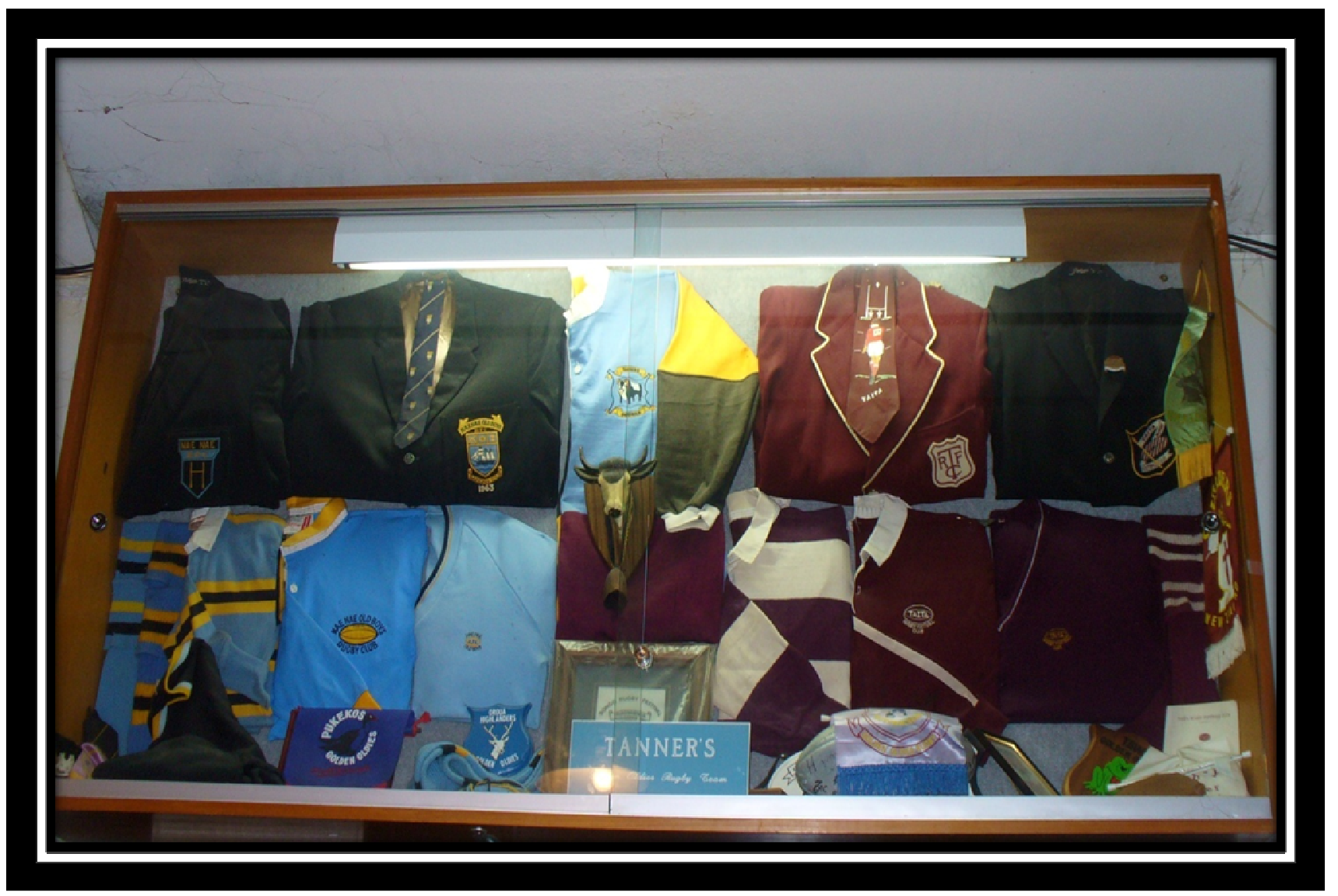

Fig 9: Club jerseys as they have changed over the years 


\subsubsection{Memorabilia/Ephemera}

This is a collection of items which commemorate special events. It can include programs, badges, and clippings, gifts from visiting clubs, books, glassware, ties and playing jerseys.

When visiting a club room and there is a display cabinet of memorabilia there will always be someone looking at it. In many ways it is a small museum of that particular club.

It has been a tradition within rugby clubs when visiting other clubs to present a gift for the hospitality they have received and this is often in the form of a club tie or jersey. Clubs will on occasion entertain teams from other countries and clubs have special display cases with jerseys from overseas.

A particular focus for the preservation of jerseys and memorabilia is when a player from a club has reached the pinnacle of rugby and become an All Black. That club member may present to the club his All Black jersey, photos and other special items and these will be put into a special display case in his honour.

Table 9 shows only one club has control of its memorabilia. It knew what was in storage, where it had come from and had part of the collection displayed. Three clubs had no idea where to locate any items and would have to advertise to get past members to donate any items they may have.

\begin{tabular}{|l|c|c|c|}
\hline & Yes & No & Don't know \\
\hline On display in cabinets & 1 & 6 & 0 \\
\hline $\begin{array}{l}\text { Jerseys from other clubs } \\
\text { or countries on display }\end{array}$ & 5 & 2 & 0 \\
\hline Stored elsewhere & 1 & 3 & 3 \\
\hline Stored at club & 4 & 1 & 2 \\
\hline Catalogue of what is held & 1 & 6 & 0 \\
\hline
\end{tabular}

Table 9: How memorabilia is accounted for and stored 


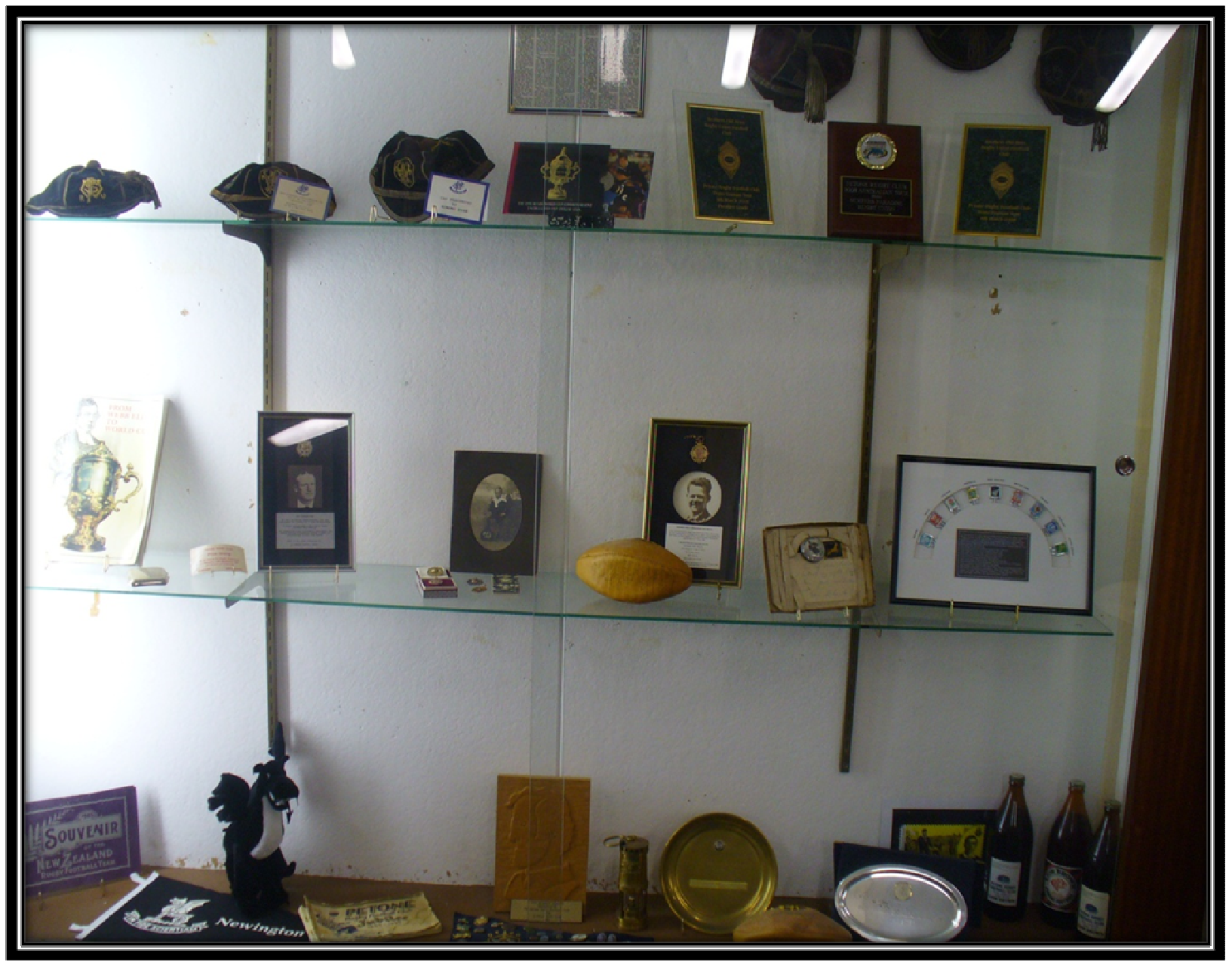

Fig10: A good example of memorabilia on display

The one club which has put preservation practices into place has sought advice from Te Papa (National Museum of New Zealand) in particular in respect of how to store and display a founder's banner made when the club was formed in 1885 . 


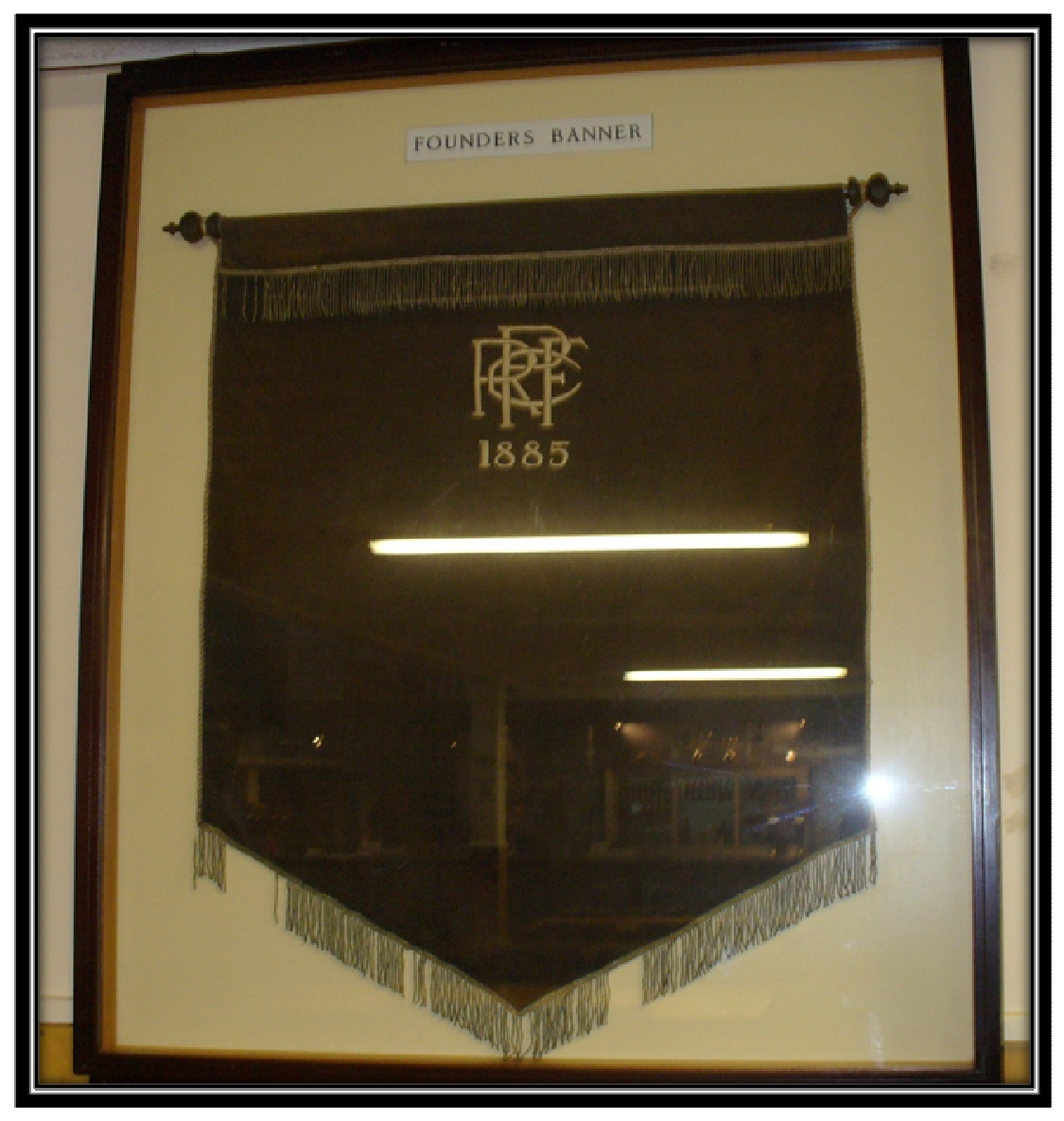

Fig 11: Display cabinet with founders banner

\subsubsection{Amalgamation of Clubs}

Two of the clubs interviewed have in the past amalgamated with another club. These two clubs were asked whether they held the past records of the clubs which made up the amalgamation.

Club one said there were some photographs, a couple of annual reports and a few jerseys but the actual minute books and other records of the two clubs cannot be found. When the need to write a history for a milestone is reached, a huge exercise will be required to gather the necessary information. 
Club two said when celebrating the centennial a book was written, taking into account the history and makeup of the two clubs. Information was gathered for this task and this is stored away in boxes. No one has looked at it for a few years so it is not known what condition the boxes are in or whether they are packed and stored correctly.

Club two has a wooden plaque on a wall describing how the two clubs came together, which they call "The Legend".

\subsubsection{Histories of clubs}

Written histories of clubs are a treasure with photographs depicting changes over time such as a photograph of the old club building and the surrounding area. They will show where certain policies or processes came from. There are stories of people (volunteers) who have helped form the club and the standing that club had within the community and how the club and the community are inter-connected. Histories will generate pride within the club.

To write up these histories it is the old records which are needed. Theses are the minute books, membership lists, annual reports, photographs, newsletters, honours boards and documents and if these cannot be located the task becomes enormous.

This leads onto another question. When clubs have reached the hundred years or decide to celebrate another milestone and if they have produced books, where is the paperwork or preparation for this? RFC6 celebrated 75 years of existence and produced a booklet but the information gathered is not stored at the club and the interviewee does not know where it is or how it is being stored. A lot of the information used will be original and should be stored according to preservation standards.

These issues were only discussed with three of the seven clubs but the issues will apply to all of them. 


\subsubsection{Does the club have a newsletter?}

\begin{tabular}{|l|c|c|c|}
\hline & Yes & No & $\begin{array}{l}\text { Don't } \\
\text { know }\end{array}$ \\
\hline Does the club have a newsletter? & 3 & 2 & 2 \\
\hline How is it distributed - website? & 1 & 4 & 2 \\
\hline How is it distributed - paper? & 2 & 3 & 2 \\
\hline $\begin{array}{l}\text { Does the club have a complete set of } \\
\text { newsletters? }\end{array}$ & 0 & 0 & 7 \\
\hline
\end{tabular}

Table 10: Newsletter produced by the clubs

Newsletters are a great source of information and can include profiles of members, tributes to members, events of the day, game results and advertising. The older the newsletter the better as it contains many memories and photos of the past. Members, particularly those who live away from the area enjoy receiving the newsletter as it keeps them up to date with what is happening at the club and gives a sense of belonging.

Two clubs were not asked this question. As table 10 shows three clubs produce a newsletter but the frequency of producing it varies. Two clubs produce a weekly newsletter. RFC3 has these available to members via the club web site and RFC5 either hands them out on Saturday or post where necessary. The interviewee at RFC3 did not know if a hard copy was being produced and saved. RFC7 produce a newsletter when teams are playing a home game as it can be handed to members with only a few having to be posted out. RFC6 previously produced one but this has ceased and the club is looking for someone to take on this task. The club distributes a notice about old timers' day (a day when the club recognises previous players and members). Not one club was sure if there was a complete set of newsletters or when the newsletter commenced. 


\subsubsection{Use of computers for club activities}

The question of where committee members are preparing club administrative documentation is an important one. Where has everything been backed up to? If committee members are using their computer at work for club matters are they breaching work place rules? If they are using the computer at home and the computer is stolen or crashes all the information is lost. How can other members access this information? Also by having a club letterhead template on a home or work computer could it be used for the wrong reasons?

RFC6 had a year's minutes lost when a home computer crashed. Other members did have copies but it was extra work to locate and recreate the minutes file.

If members are writing correspondence at home or work are they printing and filing that correspondence? Is it just sent to the recipient by e-mail without a hard copy made? When a reply is received by e-mail is that printed and filed?

Table 11 shows that four clubs provide computers at the club which can be used by everyone but it would appear that more club matters are attended to on home or workplace computers. If a task is only going to take a few minutes it may not be convenient or practical to go to the club to deal with it.

The secretary at RFC4 once a year transfers all the club information on the computer at home to the club computer. This is a good example of making sure the information is available at the club for future reference and use. A concern with this is the possibility of the home computer being stolen or crashing. A more regular transfer would be preferable.

\begin{tabular}{|l|c|c|c|}
\hline & Yes & No & Don't know \\
\hline Committee use computer at work & 2 & 3 & 2 \\
\hline Committee use computer at home & 6 & 0 & 1 \\
\hline $\begin{array}{l}\text { Club has an office with computer } \\
\text { provided for all to use }\end{array}$ & 4 & 3 & 0 \\
\hline
\end{tabular}

Table 11: Computer usage by members 


\subsubsection{Copies of original club rules and certificate of incorporation}

The original rules of the club can be very interesting. Here can be found a description of the club colours, the makeup of the committee, the conduct expected of players and the distribution of funds if the club is wound up as examples of interest. The rules will also state the reason why the club is being formed and what the club is trying to promote. Over time the rules will have changed and one of the biggest changes is that the original set of rules will state how many club members make up a quorum at a meeting when a vote is required on an item of business. The original rules may state as many as $50 \%$ of members must be in attendance but the number required today may have changed to as few as $20 \%$. This has come about because of poor attendance at Annual General Meetings and clubs have had to change their rules to allow for this. The rules will show how within the community topics have changed and how in some cases rules have become more complex as society has changed.

Table 12 shows not all clubs have the original certificate of incorporation or rules. RFC 1 said that information is available on the Incorporated Societies web site and can be printed off if required. This is not the original typed certificate of incorporation but a computer generated certificate which does not have the historic appeal of the original.

\begin{tabular}{|l|c|c|c|}
\hline & Yes & No & Don't know \\
\hline Copy of original rules of the club & 3 & 1 & 3 \\
\hline Copy of the original certificate of incorporation & 1 & 2 & 4 \\
\hline $\begin{array}{l}\text { Set of rules with all the changes as they have } \\
\text { been made }\end{array}$ & 2 & 2 & 3 \\
\hline
\end{tabular}

Table 12: Rules and Certificate of Incorporation 


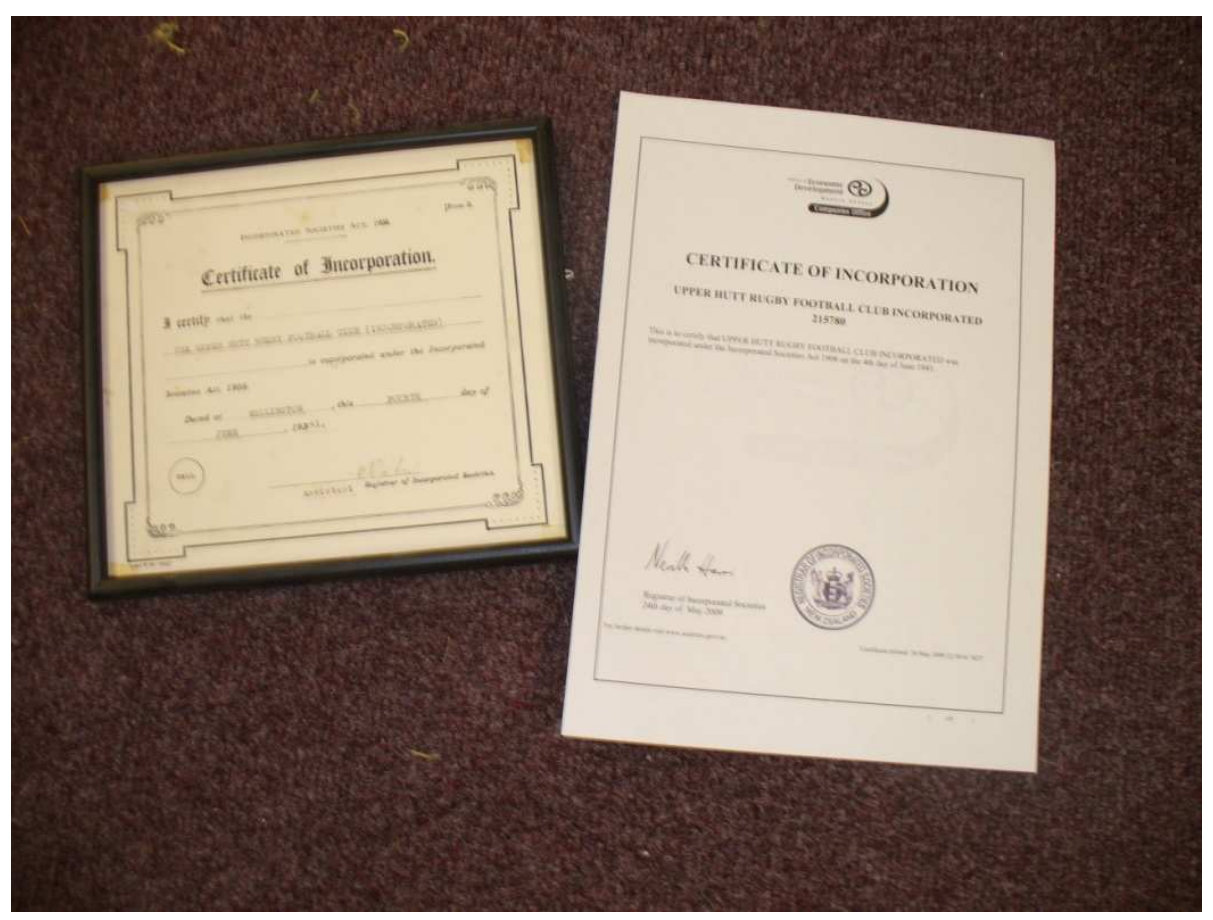

Fig 12: Comparison between original and computer generated Certificate of Incorporation

\subsubsection{How is information on members kept?}

The members that make up the club are an important ingredient. Without its members there would be no club.

\begin{tabular}{|l|c|c|c|}
\hline & Yes & No & Don't know \\
\hline $\begin{array}{l}\text { Club uses WRFU database of playing } \\
\text { members. }\end{array}$ & 4 & 2 & 1 \\
\hline $\begin{array}{l}\text { Club has a database of playing } \\
\text { members. }\end{array}$ & 5 & 2 & 0 \\
\hline Club keeps statistics on games played. & 2 & 1 & 4 \\
\hline Database of financial members kept. & 2 & 2 & 3 \\
\hline $\begin{array}{l}\text { Club provides a history of players if } \\
\text { they reach representative status. }\end{array}$ & 5 & 1 & 1 \\
\hline $\begin{array}{l}\text { Club has a database of non-playing } \\
\text { members. }\end{array}$ & 5 & 1 & 1 \\
\hline
\end{tabular}

Table 13: Club membership 
Members are made up of those that play the game of rugby and non-playing members who are often those that have finished their playing career but still want to have the sense of belonging to the club. They are also known as supporters, old timers or the fans that come to watch the game being played. All members both playing and non-playing are asked to pay a subscription although some clubs are only just starting to charge a subscription to nonplaying members. The financial support given to a club through the subscriptions paid is required to cover administration costs and playing costs (jerseys, training equipment etc.). To be able to find out who has paid is vital for the financial welfare of the club so to have a database of financial players is very important yet only two clubs can confirm that they have a record of financial members.

When a player registers for a season, a registration form must be filled out and signed. The form is then forwarded on to the Wellington Rugby Football Union which each year updates its database. All players must be registered. This database does not record any non-playing members and clubs have to keep this database themselves. Table 13 shows that five clubs are doing this.

Table 13 shows that only four clubs make use of the service provided by the WRFU which gives free access to the list of playing members. Five clubs have their own database and of these five only two use both databases.

Keeping statistics on a player and the game will show how a player has developed over time and assist in the end of year decisions on who should win cups or prizes depending on how they have performed during the year.

Five clubs said they could provide a history of their players if required and RFC5 has an excellent database of members. When a person first joins this club their name is entered onto 
a worksheet and when that member has been financial for three years the name is transferred to an index card. The card is updated each year but when that member moves away the card does not get updated. This system although outdated is working and when asked about a member who only played for one year the record was found. When planning for a celebration this type of data base is invaluable as the club will be able to find all past members. The one problem will be keeping the system up to date when the keeper of the cards moves on. A solution would be to transfer the system to a database for future ease of access in case no one could be found to carry on the present system.

\subsubsection{Annual Reports}

An annual report is presented at the annual general meeting and consists of a chairman's report, team reports, audited financial accounts, team photos and may also list life members, committees and members of the club. The information contained in these reports records the growth of the club, major decisions, lists of trophy winners, committees, lists of members, events held during the year and the financial situation. These reports are a frozen picture in time depicting the activities of that year.

In the past most clubs had the annual report produced by a professional printer but with the increasing ease and the ability of being able to produce booklets on personal computers the need to have a copy officially printed has decreased.

As table 14 shows with the increasing cost of printing reports, four clubs do not produce a booklet but distribute loose reports at their annual general meeting. Of the three club reports seen, two, in the form of booklets, contained all the above information. The third report which was in the form of loose papers did not contain all that information. 
When asked if a complete set of reports was available only two clubs could comply. RFC6 had a partial set and four clubs had no knowledge of what they held or where they were held. Annual reports contain many memories of the club and the community surrounding it. The chairman's report can often give a wide picture of events and at the time of awarding a life membership there will be information about the recipient and the reason for the award.

\begin{tabular}{|l|l|l|l|}
\hline Annual Report & Yes & No & $\begin{array}{l}\text { Don't } \\
\text { know }\end{array}$ \\
\hline Booklet produced & 4 & 3 & 0 \\
\hline In the form of loose pages & 3 & 4 & 0 \\
\hline Contains Chairman's report & 5 & 0 & 2 \\
\hline Contains team reports & 5 & 0 & 2 \\
\hline Contains financial reports & 7 & 0 & 0 \\
\hline $\begin{array}{l}\text { Does the club have a complete set of } \\
\text { Annual Reports? }\end{array}$ & 2 & 1 & 4 \\
\hline
\end{tabular}

Table 14: Annual General Meeting reports

\subsubsection{Aware of the Storage Standard by Archives New Zealand?}

The Storage Standard (2007) produced by Archives New Zealand is a mandatory standard for Government Departments but can be used as a guideline for other organisations and clubs. This standard sets minimum requirements for storage of physical records and archives such as paper files, photographs, microfilms, maps and plans.

As Table 15 shows nearly all those participating did not know of the Storage Standard. RFC2 was only aware of it as the interviewee has a work colleague in a government library and she had mentioned what to do with some archives and why. RFC4 stated that they had had a tidy up in the summer and put items in a steel cabinet which would give protection in the case of a fire. By doing this the club would partly comply with the standard. When asked if they had put any of the Storage Standard in place most clubs did not think so. In fact most clubs are complying in some small way. This has shown up in the answers to other 
questions. Clubs are looking at boxing, taking down photos from direct sunlight and seeking advice from Te Papa.

\begin{tabular}{|l|c|c|c|}
\hline & Yes & No & Don't know \\
\hline Aware of the Storage Standard. & 2 & 5 & 0 \\
\hline $\begin{array}{l}\text { Have you put any of the Storage } \\
\text { Standard into practice? }\end{array}$ & 2 & 5 & 0 \\
\hline
\end{tabular}

Table15: Aware of Archives New Zealand Storage Standard

An example of current storage practice is shown in Figure 13. RFC5 does have a storage cupboard but it is against a concrete block wall. It is difficult to get to the cupboard as it is in the general storage area for the club. There is a selection of paint containers and other material in front of the cupboard doors. Inside the cupboard are the minute books, starting from commencement of the club with the first book being leather bound.

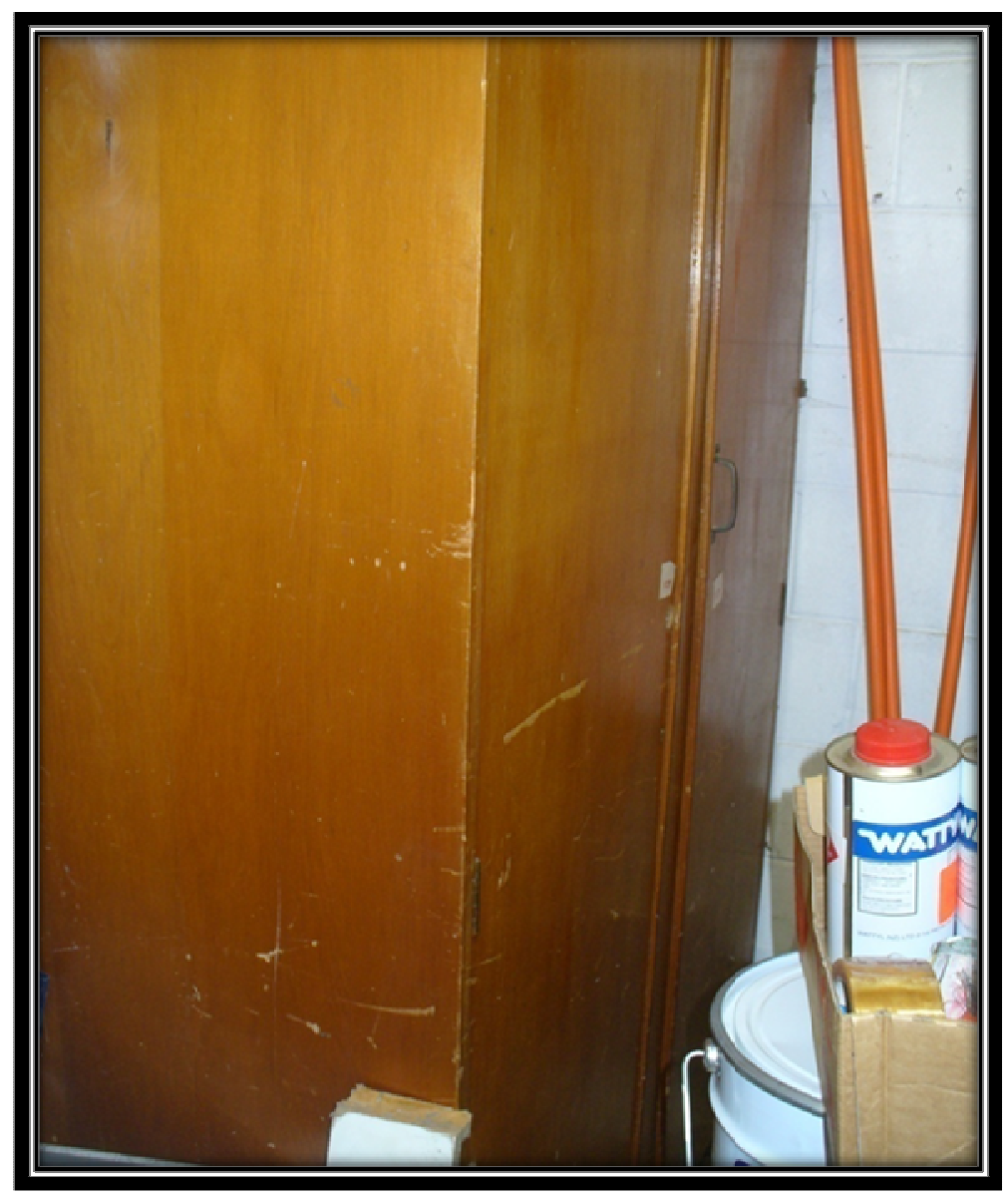

Fig 13: Storage cupboard which holds minute books, finance and correspondence 


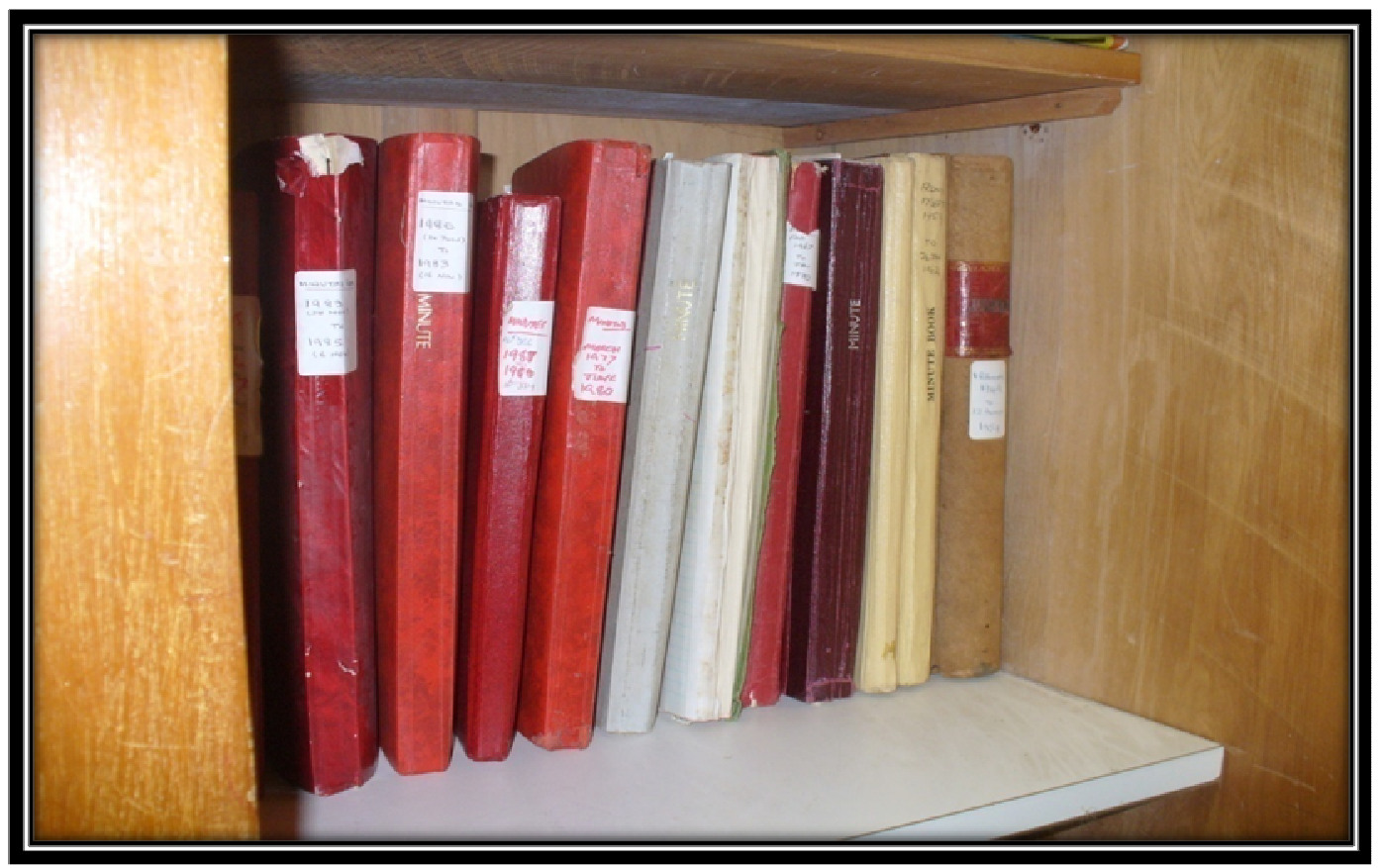

Fig14: Minute books inside the cupboard

Figures 15 and 16 show records stored loose on shelving and in a cupboard. All the records are exposed to all categories of harm that should be addressed with a preservation programme.

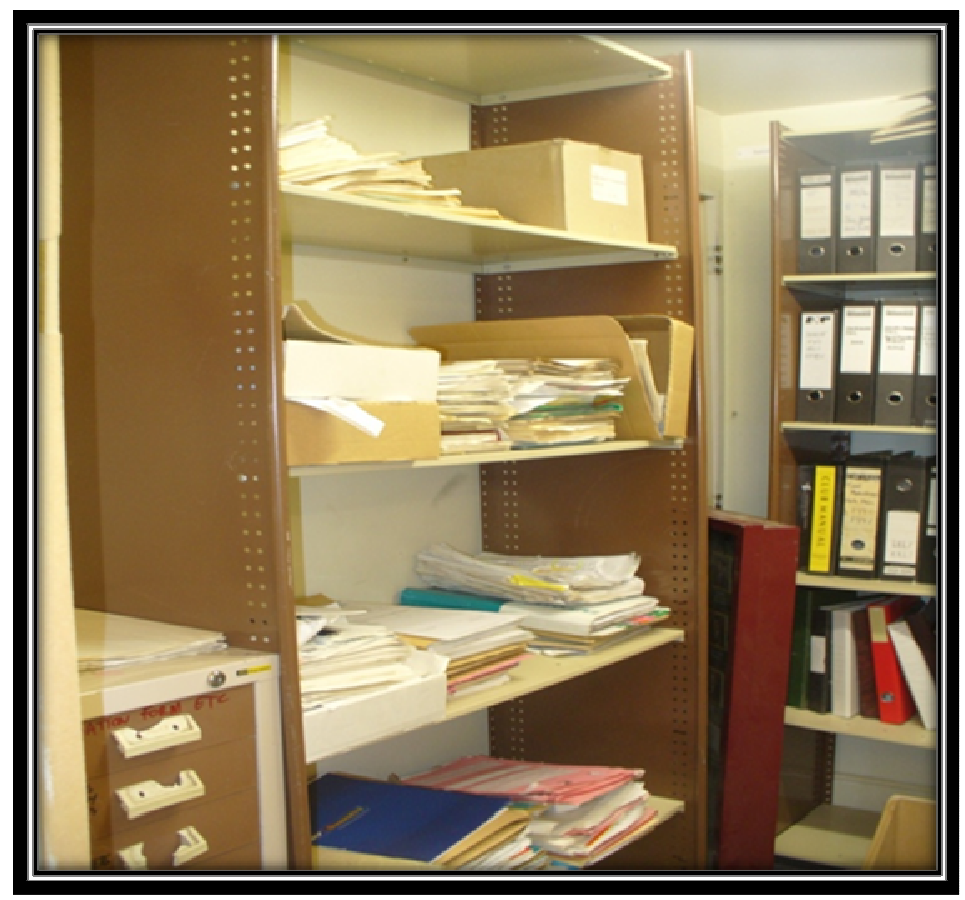

Fig 15: Shelving with loose papers 


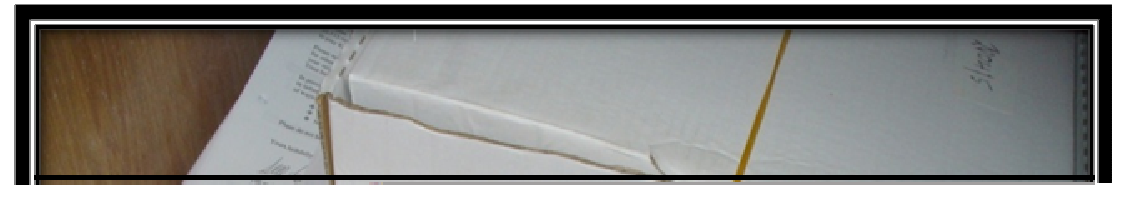




\begin{tabular}{|l|c|c|c|}
\hline & Yes & No & Don't know \\
\hline $\begin{array}{l}\text { Aware of } \\
\text { Archival } \\
\text { Institutes }\end{array}$ & 1 & 6 & 0 \\
\hline $\begin{array}{l}\text { Deposited with } \\
\text { Archival Institute }\end{array}$ & 1 & 4 & 2 \\
\hline $\begin{array}{l}\text { Have their own } \\
\text { archives }\end{array}$ & 2 & 4 & 1 \\
\hline
\end{tabular}

Table 16: Knowledge of archival institutions

\subsubsection{Producing guidelines}

When asked if the club would be interested in having a book, a manual or a guideline of archival practices all clubs could see the benefits and all seven clubs embraced the idea as shown in table 17. When first approached to participate in this research several clubs said their records were in a mess and not looked after properly.

The idea of a guide or manual will be discussed in the conclusion and recommendations. It is important to have something that is not written in too complex terminology and is easy to follow. A list of contacts for advice would be well received

In the majority of cases club volunteers do not know where to go to find out what they should be doing.

One of the major problems expressed by the clubs was who is going to do this work? Would it create more work for the already overburdened volunteer? RFC4 asked would the club need to find an archivist who would do the job for them on a voluntary basis? These questions need to be taken into consideration. 


\begin{tabular}{|l|c|c|c|}
\hline & Yes & No & Don't know \\
\hline $\begin{array}{l}\text { Interested in a } \\
\text { guideline for } \\
\text { Archival Practices }\end{array}$ & 7 & 0 & 0 \\
\hline
\end{tabular}

Table 17: Guidelines for archival practices

\subsection{Conclusion}

The interviews were successful with most clubs giving full answers where possible. In some cases the interviewee was unable to answer the question as it was not known how the process was done or whether anything was being done. As it is the rugby playing season and all club officials are volunteers it took several attempts to get a suitable time to do the visit and interview. Once all interviews were transcribed the average time for transcribing was eight hours. A full observation was not able to be done at all clubs as not every archival item is held there or the items are inside a locked cupboard.

Once each question folder had all the seven clubs answers it was relatively easy to code the answers and to see what preservations practices were being actioned.

All clubs agreed that photographs could be taken and these photographs show the different standards that are being practiced and illustrate the need for the study. 


\section{Chapter Five: Conclusions and recommendations}

\section{Introduction}

The goal of this research was to investigate:

1. To what extent are volunteers in clubs aware of archives best practice?

2. To what extent are these guidelines being practiced?

3. What are the implications of not following the best practice guidelines?

In the conclusion the findings of the research have been summarised under each research question heading to establish whether the question has been answered and whether it confirms what was said in the literature review. There is also a summary of how the clubs conform to the recordkeeping continuum described in the theoretical framework. There are some issues the clubs need to address if they are to improve their archival practices and these are included in this chapter. The recommendations are achievable if the right support and backing can be applied.

\subsubsection{Aware of archives best practice}

The findings from this research show that the volunteers are not very aware of what archival practices are or what they should be doing to protect their archives. This becomes evident when listing what guidelines are being practiced. From the observations made the archives are not an important aspect of the clubs' activities and it is not until planning a milestone event such as the first fifty years or the centennial that it becomes noticeable records have not been kept and the search goes on to locate what is missing.

\subsubsection{Guidelines being practiced}

Only one club shows any great interest in this area by seeking advice from Te Papa as to what they should be doing. They have already got duplicate photos on display and are in the 
process of building a special archival area. A second club is about to build a room but it may not meet archival standards.

Clubs without being aware have in a small way been practicing archival guidelines by, for example, maintaining a minute book or file, keeping the main trophy and handing out a replica at prize giving and displaying a duplicate photograph.

\subsubsection{Implications of not following the best practice guidelines}

Apart from the one club which is well on the way to implementing best practice guidelines the other six have in various ways highlighted what the implications are of not carrying out some form of archive best practice.

Failure to follow best practice guidelines can result in:

Minute books lost

Records on home computer lost

Photographs damaged by sunlight

Photographs damaged by poor storage standards

Trophies with no history recorded

Historical documents lost

No cataloguing done (in the case of theft or loss how can the information be replaced?)

Past members of the club not able to be traced

\subsection{To put the above into a recordkeeping continuum aspect}

1. Create: How are the clubs doing this? All clubs are creating minutes, correspondence, financial records and annual reports. When clubs are creating information on 
players where do they keep this? Five clubs are using a database of some sort, one has a manual system using card indexes and one club did not know the answer.

2. Capture: It appears that the clubs vary in the way they capture information. All clubs capture their minutes in an electronic format but with correspondence this is divided between electronic capture and a paper record. Annual reports are presented in two formats, a printed booklet or loose papers. Where the information is captured is also a problem. Four clubs provide computers at the club to use but are the members using these or the computers at home or work? If this information is saved into the work or home computer it is not accessible by others.

3. Organise: It is this area that shows the biggest risk. With little knowledge of archival practices the clubs filing and storage of information needs attention. Five clubs lack organisation within their archives. One club had built a room for their archives, a second club has built a room but this is to be shared with other items, therefore not complying with the storage standard. Only one club had catalogued their photographs, all the other clubs had photographs in various situations, on walls, in boxes, behind doors, and stacked on top of each other with the glass of framed photographs broken. Loose paper was stored on shelves, in boxes, tied up with string or rubber bands and in cupboards. This form of storage does not protect the archives from the elements of temperature, light, pests, and general deterioration.

4. Pluralise: The way the archives are stored in cupboards, club members' houses and not even knowing where they are does not make access easy. Two clubs have met 
this challenge. RFC3 has started to create an archive and has many of its archives on display and is seeking archival advice on how to do this. RFC6 has lodged the minute books at a local library.

When considering what should be done there are three main issues for clubs.

1. The first is finding the volunteers to take an interest in the archives and give the time needed to put practices into action. It is becoming more difficult to find the people who have the time to give (this applies to many organisations and not just rugby clubs). People do not stay on committees for any length of time and the question of continuity needs to be addressed.

2. The second is funding to implement practices. To be able to do what is required to put archival practices in place costs money. If the club has the space to provide a purpose built room it will need funds to do so. It will cost to put in place a programme to digitise all the photographs.

3. The third issue is where do the clubs go to find out about archives, preservation, how to create records and what is required of them to preserve their records for the future?

\subsection{Recommendations}

When the clubs were asked whether a manual or guideline in archives practices would be helpful they all answered yes with the following comments being made:

"A lot of people just fall into these positions and have no training"

"People are volunteers and not trained for those jobs"

"I fully agree with what you say"

"A good idea" 
"The WRFU should probably take some responsibility in helping clubs preserve their history"

"Having a manual would be great as committee member's change and this would mean that the job could continue without any disruption"

At present there are a lot of pamphlets available and information can be downloaded from the internet. These sources usually deal with a specific topic and what is required here is a complete package covering all preservation topics.

The recommendation is that further research be done into the possibility of producing a manual or guidelines of archives practices for the rugby clubs within New Zealand. Backing would be required for a project like this and there are several organisations which would stand to gain from this type of venture.

\author{
New Zealand Rugby Union \\ Archives New Zealand \\ SPARC \\ Local City Archives
}

There are three guidelines available which could be used as an example.

Toolkit for Community Archives (2009)

Managing and Preserving Community Archives (2005)

New Zealand Theatre Archives (2005)

Each of these publications is well presented but there is a need for a manual specifically for rugby clubs to cater directly for those preservation issues which affect the clubs. 


\subsection{Conclusion}

In conclusion rugby has been played in New Zealand for many years and the memories and local history within these clubs needs to be retained and made available for researchers to use to write the histories of the clubs and of the local communities. Rugby clubs are at the "grassroots of the community." Some members of rugby clubs commenced playing at age five and have stayed with the club over the years as players, then coaches and finally taking a place on the committee. At one part of their playing career all our All Blacks would have been members of a local club and the information about their playing career should be preserved within the club.

It is this local history which must be saved and protected.

Word Count 14,797 

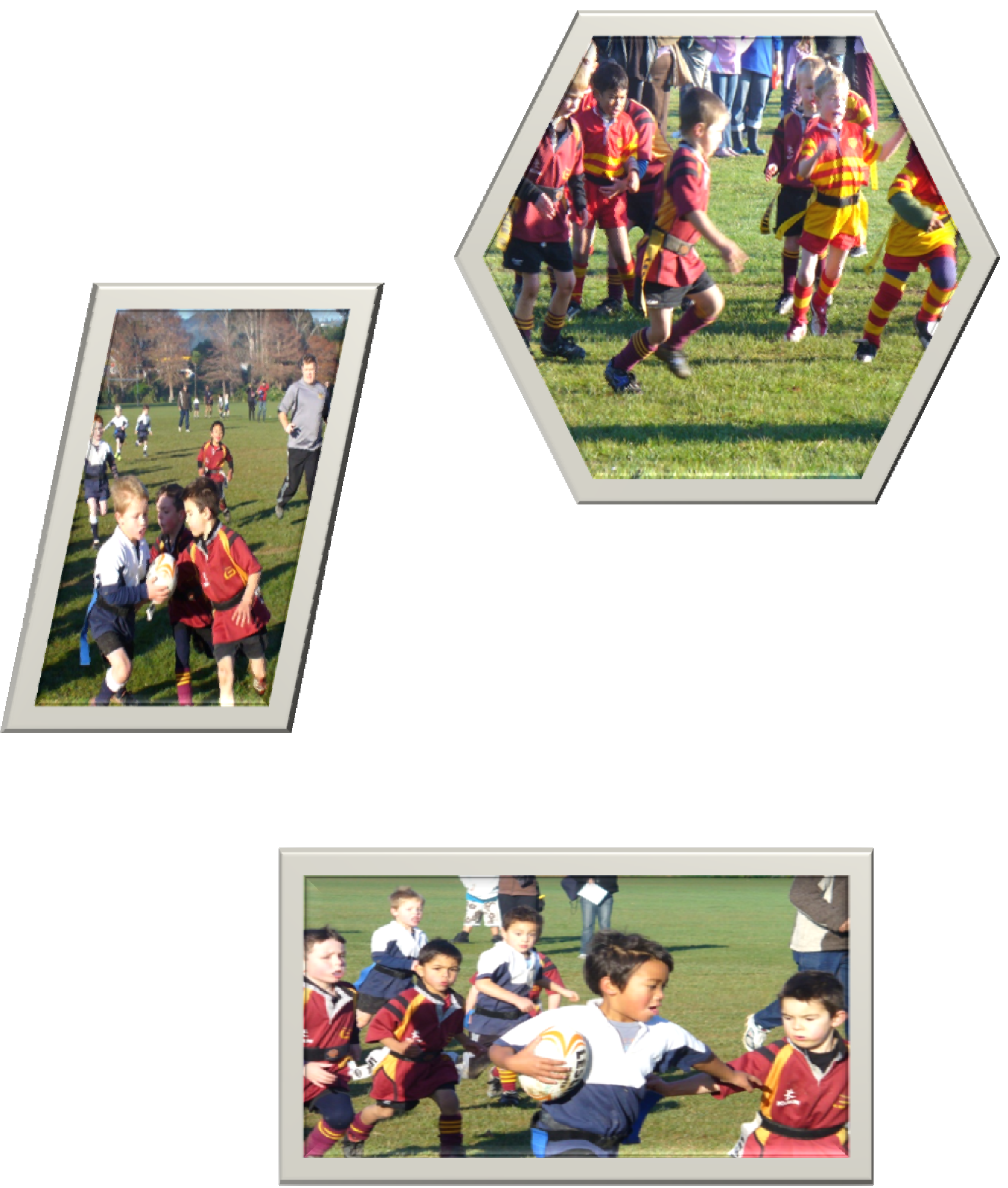

Fig 17: We need to preserve the memories of the past for the future. 


\section{Reference List}

Archives New Zealand (2005). GDA/1. General Disposal Authority. Human Resources and Personnel Records. Wellington, New Zealand.

Archives New Zealand (2006). Continuum create \& maintain - glossary of archives and recordkeeping terms. Recordkeeping Guides G/5.

Archives New Zealand. (2007) Storage Standard: Standard for the Storage of Records and Archives. Wellington, New Zealand

Archives New Zealand. (2009). Toolkit for Community Archives. Wellington, New Zealand

Bansal, A., Kumari, V., Kumar, A., \& Singh, M. (2005, January). Securing the Future of Information: Digitisation and Preservation of Documents in e-Format. DESIDON Bulletin of Information Technology, 25(1), 19-26.

Brown, S., Cole, I., Daniel, I., King, S., \& Pearson, C. Guidelines for Environmental Control in Cultural Institutions. Heritage Collection Council, Canberra, Australia

Collier, R. \& Graham, R. (Eds.). (2005) Caring for your theatre archives. Wellington, New Zealand

Cook, T. (2000, August.) Beyond the screen: The records continuum and archival cultural heritage. Paper presented at the Australian Society of Archivists Conference, Melbourne.

Cox, R.J. (2005, October). Archives and communities: The ways of the document. Paper presented at the Joint Australian Society of Archives and Archives \& Records Association of New Zealand Conference, Wellington, New Zealand.

Creswell, J.W. (2002). Research Design: Qualitative, quantitative and mixed methods Approaches ( $2^{\text {nd }}$ ed.) Thousand Oaks, CA: Sage

Dawson, E., Dodd, R., Roberts, J. \& Wakeling, C. (2004). Issues and challenges for records management in the charity and voluntary sector. Records Management Journal. 14(3), 111-115.

Hall, R. (2004). The Elgar Society archives: Managing the records of a voluntary society. Records Management Journal. 14(3), 129-132.

Kennedy, J., \& Schauder, C. (1998). Records Management: A guide to corporate record keeping $\left(2^{\text {nd }}\right.$ ed). South Melbourne: Addison Wesley Longman.

McKemmish, S. (2005). Traces: Document, record, archive, archives. In S. McKemmish, M. Piggott, B. Reed, \& F. Upward (Eds.) Archives: Recordkeeping in Society (pp.1-20) Wagga Wagga, NSW: Centre for Information Studies.

Munro, D. (2000, October). Rescuing the Star Boating Club records. Archifacts. 43-46. 
Museum of New Zealand, Te Papa. (2001) Preventive Conservation Resources Guide. Wellington. New Zealand

National Preservation Office. (2005) Managing and Preserving Community Archives. Wellington. New Zealand: p27

National Preservation Office, Te Tari Tohu Taonga. (2006). Caring for TaongaPhotographs. Wellington. New Zealand: p23.

National Register of Archives \& Manuscripts (NRAM). Accessed 11 January, 2009 from: http://www.nram.org.nz

New Zealand Government. (2007). Income Tax Act 2007: Wellington, New Zealand

New Zealand Government (1993). Privacy Act 1993: Wellington, New Zealand

New Zealand Government. (2005). Public Records Act 2005: Wellington, New Zealand

New Zealand Rugby Union. Best Practice Manual. Accessed 18 January, 2009 from: http://www.nzrugby.co.nz

Picard, A.J. (2007). Research Methods in Information. London: Facet Publishing.

Presbyterian Historical Society Records Preservation. www.history.pcuse.org/cong/records/preservation.html last accessed 27 July, 2008

Oxford English Dictionary. www.askoxford/com/concise last accessed 11 January 2009

Smith, A. (1998, September). Archives - Core Business for Rail Museum Futures. New Zealand Archivist, 9(3), 2-5.

Smith, A. (1999) Why Digitize? Council on Library and Information Resources. Washington, D.C. Retrieved 4 August 2008 from http://www.clir.org/pubs/reports/pub80smith/pub80.pdf

Sogunro, O.A. (2002). Selecting a Quantitative or Qualitative Research Methodology: An Experience. Education Research Quarterly, 26(1), 3-10.

Sport \& Recreation New Zealand (SPARC). Writing your club history. Retrieved 18 August, 2008 from http://www.sparc.org.nz/sport/running-your-club/running-your-club/writing-yourclub-history

The Directory of Archives in New Zealand - Ngā pae mahara. (2006) Wellington, New Zealand. Archives New Zealand

Wellington Rugby Football Union. Wellington Clubs www.wrfu.co.nz/community-rugby/wellington-clubs last accessed 5 January 2009 
Upward, F. (2000). Modelling the continuum as paradigm shift in recordkeeping and archiving processes, and beyond - a personal reflection. Records Management Journal, 10(3), 115-139.

\section{Bibliography}

Australian Society of Archivists. (2008) Keeping Archives ( ${ }^{\text {rd }}$ ed.) Virginia, Qld: Australia

Flinn, A. (2007). Community Histories, Community Archives: Some Opportunities and Challenges Journal of the Society of Archivists. 28(2), 151-176.

Gibbs, G.R. (2002). Coding. In Qualitative Data Analysis:

Buckingham: Open University Press.

Library of Congress. Preservation.

http://www.loc.gov/preserv/ last accessed 18 January, 2009

Newton, N. (2004). Trumpeting the voluntary in the United Kingdom. Records Management Journal. 14(3), 107-110.

Society of American Archivists. (1995). A Guide to Donating Your Organizational Records to a Repository [Brochure]: SAA Manuscripts Repositories Section

Stapleton, A. (2006/2007). Beyond Post-custodial: Relinquishing the 'Glass Bead Game'. Archifacts. October 2006 - April 2007, 29-48. 


\section{Appendix 1: List of Wellington Rugby Clubs}

\section{Club}

Avalon RFC (1980)

$\underline{\text { College Old Boys-Victoria University (1992) }}$

Eastbourne RFC (1921)

Hutt Old Boys-Marist RFC (1993)

Johnsonville RFC (1900)

Marist-St Pat's RFC (1971)

Northern United RFC

Oriental-Rongotai FC (1968)

Paremata-Plimmerton RFC (1959)

Petone RFC (1885)

Poneke FC (1883)

Rimutaka RFC (1982)

Stokes Valley RFC (1949)

Tawa RFC (1947)

Upper Hutt RFC (1920)

Wainuiomata RFC (1946)

$\underline{\text { Wellington FC (1871) }}$

Western Suburbs RFC (1983)

\section{Colours}

Maroon \& Blue

Green, White \& Black

Forest Green \& Gold

Red, Emerald Green \& White

Dark Blue \& Light Blue

Scarlet, White, Dark

Blue \& Green

Blue \& White

Black, White \& Gold

Black, Scarlet \& Gold

Navy Blue \& White

Red \& Black

Orange \& Black

Red \& Gold

Red, Blue \& Gold

Maroon, Gold \& White

Emerald Green \& Black

Yellow \& Black

Blue, Red \& White 


\section{Appendix 2: Sample Letter to Institution}

14 February 2009

Dear [proposed participant institution]

My name is Christine Edney, and I am currently a Masters student in Library and Information Studies at Victoria University of Wellington. As part of this degree I am required to undertake a research project. The topic of my research is "Grassroots of Recordkeeping - An investigation into archival practices within rugby clubs in New Zealand".

I am writing to you to ask your consent to approach a total of seven clubs in the Wellington Union in order to interview key individuals.

The clubs selected will represent a wide range of formation dates and provide a wide coverage of the Wellington Union.

Interviews will investigate how routine records such as minutes of meetings, photos, information about players, annual reports, newsletters, correspondence and so on are created and managed.

The outcome of this research will be of benefit to rugby clubs in that recommendations will be made for improvement in their archive practices and these recommendations can also provide the basis for the development of a set of written guidelines. These guidelines will encourage clubs to take charge of their records from the time of creation, through the period of use and to final storage where they can be viewed by a wider audience, for example the local community and not just club members.

Participation in this study will be entirely voluntary. If you approve in principle I will then approach each selected club individually and request permission to undertake my study. Individual clubs will not be identified in the final report.

If you have any questions or would like to receive further information about this project, please contact me or my supervisor, Dr Gillian Oliver, School of Information Management, Victoria University of Wellington (E-mail: Gillian.oliver@vuw.ac.nz Telephone 463 7437).

Yours sincerely

Christine Edney

MLIS Student 


\section{Appendix 3: Reply from institution}

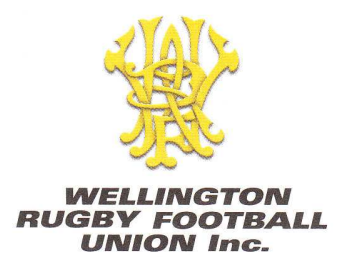

10 March 2009

Christine Edney

7B McHardie Street

UPPER HUTT

Dear Christine,

We refer to your letter of 14 February, with respect to the research project you are currently undertaking.

On behalf of Wellington Rugby Football Union, I am pleased to provide consent for you to approach a total of seven clubs to enable your research to be further advanced.

It would be appreciated if you could keep me informed of your progress throughout the project.

We wish you all the very best for the remainder of your University studies.

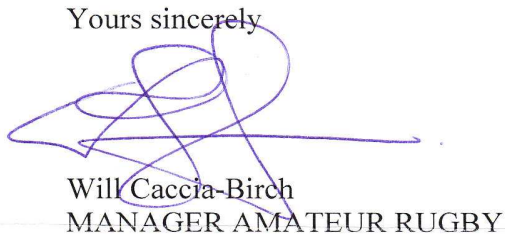

\section{Tuld CSC NZCT}

WELLINGTON RUGBY FOOTBALL UNION INC.

113 Adelaide Road, Newtown, Wellington 6021, P0 Box 7201, Wellington South 6242, New Zealand. Tel: 64-4-389 0020 Fax: 64-4-389 0889 mail@wrfu.co.nz www.wrfu.co.nz Our Vision: "Wellington Rugby to be the most successful Provincial Rugby organisation in the world with a winning tradition based on a world class performance culture" 


\section{Appendix 4: Sample Letter to Participant}

Date

The Chairman

Rugby Club Name

\section{Dear Participant}

My name is Christine Edney, and I am currently a Masters student in Library and Information Studies at Victoria University of Wellington. As part of this degree I am required to undertake a research project. The topic of my research is "Grassroots of Recordkeeping - An investigation into archival practices within rugby clubs in New Zealand".

To establish how aware rugby clubs are of the above I will be conducting a visit to several clubs and interviewing a person from that club e.g. chairman or secretary to obtain the data required. Approval for this has been sought from the Wellington Rugby Football Union and the confirmation of this approval is attached.

I would like to invite your club to participate in this research.

Interviews will investigate how routine records such as minutes of meetings, photos, information about players, annual reports, newsletters, correspondence and so on are created and managed. The interview will take the form of semi structured questions which will ask participants to describe how the club performs that task. I will be taking notes during the interview and a recording will also be made. The interview should take 60 to 90 minutes. I would also like to take a few photos to use as an example of how the club records are being maintained.

If you agree to participate please fill in the attached consent form and return to me in the supplied return envelope by 3 April 2009. I will then contact you to arrange a suitable date and time for the visit and interview.

If at any point you would like to withdraw from this study and so long as it is before the final analysis of data (7 May 2009) you can do so without providing reasons.

Participation in this study is voluntary and all information provided in the interviews will be on an anonymous basis. Once the project has been finished and submitted by the end of June 2009 all data collected will be store for two years then destroyed.

Findings from this research will be of benefit to rugby clubs as it could lead to the possible development of a set of guidelines in archival practices to assist clubs in the care and storage of their records and to encourage clubs to provide storage where they can be viewed by a wider audience, for example the local community and not just club members. 
The completed research project will be placed in the Victoria University Library and a copy sent to each participating club. The results may also be presented to a professional conference of archivists to be held in Australia in October 2009.

If you have any questions or would like to receive further information about this project, please contact me or my supervisor, Dr Gillian Oliver, School of Information Management, Victoria University of Wellington (E-mail: Gillian.oliver@vuw.ac.nz Telephone 463 7437).

Yours sincerely

Christine Edney

MLIS Student 


\section{Appendix 5: Sample Consent Form to Participant}

Researcher: $\quad$ Christine Edney, School of Information Management, Victoria University, Wellington

Title of Project: $\quad$ Grassroots of Recordkeeping

An investigation into archival practices within rugby clubs in New Zealand

I have read through the proposed interview summary for the project and acknowledge that I can contact the researcher or the University representative if I need to.

I understand that any information provided by this club in the interview process will be presented in a way so that the identity of the club and staff members will remain confidential to the researcher and supervisor.

I understand that all material collected will be kept confidential and only myself and my supervisor will have access to the answers.

I understand that I may withdraw from the project before the start of data analysis on 7 May 2009.

I understand that the data collected be used to prepare a final project report and this information may be presented at a professional archival conference and published in professionals journals.

I understand that the report will be deposited in the Victoria University of Wellington Library.

I understand that when this research is completed the information I have provided will be stored in a secure place and destroyed after two years.

I consent to the participation of this rugby club in the research project.

I would like a copy of the final research project report yes/no

Name

Signature

Title

Name of Rugby Club

Phone Number

Email address

Date

Please return this form in the stamped addressed envelope provided.

Thank you for your cooperation 


\section{Appendix 6: Participant Information Sheet}

Participant Information Sheet for a Research Project into Archival Practices within Rugby Clubs in New Zealand

Researcher: Christine Edney: School of Library and Information Management, Victoria University, Wellington

I am a Masters student in Library and Information Management at Victoria University, Wellington. To complete this degree I am required to research a topic by collecting, compiling data and writing up the results into a research project report. My research topic is "Grassroots of Recordkeeping - an investigation into archival practices within rugby clubs in New Zealand". Findings from this study will lead to the possible development of a set of guidelines in archival practices to assist clubs in the care and storage of their records. The research project has been approved by the University's Human Ethics Committee.

I have applied for and have received approval from the Wellington Rugby Football Union to invite rugby clubs within the Wellington region to participate in this research. This research will involve a visit to the club where I will conduct an interview, consisting of open ended questions with the person or persons responsible for the clubs records. I will be making notes during the interview and a recording will also be made. I will also be observing club facilities to assess what archival practices the club is carrying out and if the club is aware of appropriate preservation and storage requirement for their records. I would also like to take some photographs to highlight both good and bad practices being carried out.

The time required to visit the club and conduct the interview will be about 90 minutes.

Participation is voluntary and all research findings reported will be on an anonymous basis and will not be associated with the names of those clubs participating. All material collected will be kept confidential. Only my supervisor Dr Gillian Oliver and myself will have access to the answers. The report will be submitted for marking to the School of Information Management and a copy deposited in the University Library. The results may also be presented at professional archival conferences, and published in professional journals.

All questionnaires and material gathered will be destroyed two years after the end of the project. If at any point you would like to withdraw from this study and so long as it is before the final analysis of data (7 May 2009) you can do so without providing reasons.

If you have any questions or would like to receive further information about this project, please contact me at edney@ paradise.net.nz or my supervisor, Dr Gillian Oliver, School of Information Management, Victoria University of Wellington (E-mail:

Gillian.oliver@vuw.ac.nz Telephone 4637437. 


\section{Appendix 7: Interview Guideline Sheet}

\section{Interview Guide}

The following will form the structure of the semi-structured questions to be asked at the interview. The questions asked are a lead in to information being submitted freely and where necessary prompted to extract further information.

1. Please tell me what your role in the club is

Prompt if required - Is there anyone else responsible for the records of the club?

2. As a club you will hold regular committee meetings. How are the minutes created?

Prompt if required - Where are the minutes kept?

3. With reference to the correspondence the club would receive and post out. How is this processed?

Prompt if required - What about e-mails

4. How is the information on players kept? Does the club maintain a database of players?

Prompt - At present this club has ?? players who have reached All Black status what background on their playing career do you have?

5. This club was formed in ???? Do you have a copy of the original certificate of incorporation?

Prompt if required

Rules of the club from the first set of rules to all the changes that may have been made

6. Every year the club is required to hold an Annual General Meeting is an annual report produced for this?

Prompt if required - Is the annual report in book form?

What does it contain - a report on each team and how they have done for the season

7. The photographs of the teams taken over the years as well as important events how have you stored these?

Prompt if required - Do you have a photo for every team?

8. Does the club have one computer for all to use?

9. How are the financial records created and maintained?

10. Are all the records, photos, memorabilia kept in one place?

11. Are you aware of any preservation practices?

12. Are you aware of the Storage Standard produced by Archives New Zealand? 